\title{
COMPARING EMPLOYER SANCTIONS PROVISIONS AND EMPLOYMENT ELIGIBILITY VERIFICATION PROCEDURES IN THE UNITED STATES AND THE UNITED KINGDOM
}

\author{
Renée Suarez Congdon*
}

\section{INTRODUCTION}

The number of unauthorized migrants ${ }^{1}$ in the United States and the United Kingdom has grown exponentially. ${ }^{2}$ Recent estimates indicate there are 11.6 million illegal migrants in the United States and a minimum of 510,000 in the United Kingdom. ${ }^{3}$ Not surprisingly, these huge increases have corresponded with a growing feeling of discontent about the situation in both countries. ${ }^{4}$ Illegal aliens have been associated with artificially-low wages; ${ }^{5}$

* J.D. candidate at Indiana University School of Law-Indianapolis, expected May 2008. The author would like to thank María Pabón López, Associate Professor of Law, Indiana University School of Law-Indianapolis, for her invaluable guidance and assistance with this Note.

1. The words illegal migrants, illegal aliens, illegal workers, undocumented workers, and unauthorized migrants are used interchangeably throughout this Note. Because this Note only addresses economic migration, all of these words are used to indicate individuals who do not have authorization to work in a specified country. In the United States, this includes individuals who have entered the country illegally or remained in the country without authorization. In the United Kingdom, this includes individuals who have entered the country illegally, remained in the country beyond the period for which they were authorized, or accepted work in a field of employment in which the individual did not have permission to work.

The author is aware of the negative connotation associated with the word "illegal" and does not intend its use to in any way be derogatory and, instead, merely uses it as a way of describing the official immigration status of the group being described. The author is also aware "the term illegal migrant contradicts the spirit and letter of the Universal Declaration of Human Rights, which establishes in Article 6 that every person has the right to recognition before the law, and in Article 7, that every person has the right to due process." PlatForm FOR INTERNATIONAL COOPERATION ON UNDOCUMENTED MIGRANTS, UNDOCUMENTED MIGRANT WORKERS IN EUROPE 14-15 (Michele LeVoy et al. eds., 2004) [hereinafter PICUM].

2. The Department of Homeland Security estimated 11.6 million unauthorized migrants resided in the United States in January 2006. MICHAEL HOEFER ET AL., OFFCE OF IMMIGRATION STATISTICS, ESTIMATES OF THE UNAUTHORIZED LMMIGRANT POPULATION RESIDING IN THE UNITED STATES: JANUARY 2006, (Aug. 2007), available at http://www.dhs.gov/xlibrary/assets/statistics/publications/ill_pe_2006.pdf. It has been estimated the unauthorized migrant population in the United Kingdom at the end of March 2005 was in the range of 515,000 to 870,000 with a central estimate of roughly 670,000 . Migration Watch UK, The Illegal Migrant Population in the UK: Briefing Paper 9.15 Migration Trends, (July 28 , 2005), http://www.migrationwatchuk.com/pdfs/MigrationTrends/9_15_illegal_migrant_pop_in_uk.pdf [hereinafter Briefing Paper 9.15].

3. HOEFER, ET. AL, supra note 2; Briefing Paper 9.15, supra note 2, at 1.

4. See Pew Research Ctr. for the People \& the Press et al., No Consensus on 
abuse of social-welfare programs, such as government-funded healthcare, education, and subsidized housing; ${ }^{6}$ increased risks of terrorism; ${ }^{7}$ the destruction of the landscape in border communities; ${ }^{8}$ balkanization by culture $;^{9}$ and increased taxes. ${ }^{10}$ These perceptions have bred public anger and resentment towards illegal migrants in both countries.

Legislators have attempted to deal with the illegal worker "problem"12 by proposing various types of new legislation. ${ }^{13}$ One approach taken by both the United States and the United Kingdom is the imposition of employer sanctions. ${ }^{14}$ The justification for imposing employer sanctions is the theory that the main incentive for illegal migration is the availability of employment in the destination country. ${ }^{15}$ If destination countries penalize employers for employing illegal workers, they will stop hiring them. ${ }^{16}$ If employers stop employing illegal workers, then there will be no incentive for illegal migration

IMMIGRATION PROBLEM OR PROPOSED FIXES: AMERICA's IMMIGRATION QUANDARY 11-18 (Mar. 30, 2006), available at http://pewhispanic.org/files/reports/63.pdf; PEW HISPANIC CTR., THE State of American Public OPINION ON IMMIGRation IN SPRING 2006: A REVIEW Of Major SURVEYS 4 (May 17, 2006), available at http://pewhispanic.org/files/factsheets/18.pdf (indicating " $[t]$ he share of Americans who see immigration as a major problem has been increasing rapidly ... . A significant majority of Americans see illegal immigration as a very serious problem and most others see it at least as a serious problem"); Sukhvinder Stubbs, Time for a New Mantra on Migration, THE GuARDIAN UNLIMITED (London), July 26, 2006, at 10, available at http://politics.guardian.co.uk/comment/story/0,1830334,00.html (noting "[r]ecent . . polls show that public concern over migration, and asylum in particular, has increased considerably over the last 10 years, despite the huge amount of political energy expended on passing draconian laws"); Andrew Green, A Government Deaf to the Wishes of the Majority, THE DAILY MAL LONDON, Sept. 7, 2006, available at http://www.migrationwatch.org/papers/p_DailyMail_27sept_06.asp (indicating seventy-five percent "of British people . . . wish to see much tougher immigration rules and, indeed, a similar percentage who want to see an annual limit to immigration").

5. Donald L. Bartlett \& James B. Steele, Who Left the Door Open?, TIMEMAG., Mar. 30, 2006, at 51, available at http://www.time.com/time/magazine/article/0,9171,995145-1,00.html.

6. Id.

7. Id.

8. Id.

9. Id.

10. MigrationWatch UK, Outline of the Problem (Jan. 2, 2007), http://www.migrationwatchuk.com/outline_of_the_problem.asp.

11. Id.; Bartlett \& Steele, supra note 5 .

12. For an interesting perspective on the underlying undocumented worker "problem," see generally Gerald P. Lopez, Undocumented Mexican Migration: In Search of a Just Immigration Law and Policy, 28 UCLA L. REV. 615 (1980-1981).

13. Eliot Turner \& Marc R. Rosenblum, Migration Policy Inst., Solving the Unauthorized Migrant Problem: Proposed Legislation in the US, (Sept. 2005), http://www.migrationinformation.org/Feature/display.cfm?id=333.

14. The term "'[e]mployer sanctions' [is] shorthand for penalties against employers who knowingly hire, recruit, or refer for a fee aliens who are unauthorized to work ...." Sen. Alan K. Simpson, U.S. Immigration Reform: Employer Sanctions and Antidiscrimination Provisions, 9 U. ARK. LITTLE ROCK L. REV. 563, 564 n.2 (1986-87).

15. Id. at 564 .

16. Id. 
to the destination countries. ${ }^{17}$ The idea of employer sanctions seems sound, assuming that the main incentive for illegal migration truly is employment, but in practice employer sanctions are not possible without an effective means of verifying employment eligibility. ${ }^{18}$ Both the United States and the United Kingdom have attempted to implement effective verification procedures, yet both have somehow fallen short. ${ }^{19}$

This Note addresses the employer sanctions and employment eligibility verification procedures used in the United States and the United Kingdom and highlights the advantages and limitations of each system. Though both of these systems have been in existence for over a decade and are currently in a state of flux, this is the first comparison of this type. Part II explores the origins of the employer sanctions provisions in each country and the pressures that eventually led both countries to adopt such provisions. Part III explains the relevant provisions and enforcement methods of the legislation adopted by each country. This section also details modifications made to the legislation since its enactment while comparing the two systems. Part IV addresses proposed improvements to the systems and concludes by recommending which modifications will have the best overall impact.

\section{ORIGINS OF EMPLOYER SANCTIONS}

\section{A. United States}

The history of undocumented workers in the United States stretches as far back as the Treaty of Guadalupe-Hidalgo in $1848 .{ }^{20}$ When Mexico turned territory ${ }^{21}$ over to the United States under this treaty, individual Mexican landowners became displaced foreign nationals in their own homes. ${ }^{22}$ Despite the long history of undocumented workers in the United States, the idea of imposing sanctions on employers who hired undocumented workers was not suggested until $1946 .{ }^{23}$ The first proposal of employer sanctions in the United

17. Id.

18. Lawrence H. Fuchs, Immigration Policy and the Rule of Law, 44 U. Pitt. L. Rev. 433, 439 (1983).

19. See infra Part III.

20. Treaty of Peace, Friendship, Limits, and Settlement with the Republic of Mexico, U.S.-Mex., May 30, 1848, 9 Stat 922.

21. In discussing illegal migrants in the United States, this Note will specifically focus on Mexican migrants, because Mexican Migrants make up the largest percentage of illegal migrants in the United States. Jeffrey S. Passel, Pew Hispanic Ctr., Unauthorized Migrants: Numbers and Characteristics 4 (June 14, 2005), available at http://pewhispanic.org/files/reports/46.pdf (stating 57 percent of unauthorized immigrants in 2004 were from Mexico and 24 percent were from other Latin American countries; all other counties combined, including Canada, made up the remaining 19 percent).

22. BILl ONg Hing, Defining America Through Immigration Policy 117 (2004).

23. Philip Martin \& Mark Miller, Employer Sanctions: French, German and US 
States actually came from the Mexican government. ${ }^{24}$

The lead up to this suggestion began with the United States' entry into World War II. $^{25}$ The need for American troops caused a labor shortage felt especially by Southwestern agricultural employers. ${ }^{26}$ The United States government officially indicated its approval of U.S. employers using Mexican labor in 1942 by entering into the Bracero Treaty with Mexico, which established a new guest worker program through which Mexican laborers ("braceros") would enter into temporary employment contracts with U.S. agricultural employers. ${ }^{27}$ Despite this legal means of migration, evidence indicates a substantial increase in illegal migration occurred during this time. ${ }^{28}$ Several factors examined in the aggregate appear to have encouraged employers to hire illegal Mexican migrants. ${ }^{29}$ First, employers could save money and avoid employment restrictions placed on employers participating in the Bracero Program by hiring undocumented workers. ${ }^{30}$ Second, illegal migration was attractive to Mexicans because the economy of Mexico could not support its population, American jobs paid better than Mexican jobs, and more Mexicans wanted to migrate than there were slots available in the Bracero Program. ${ }^{31}$ Third, even though the U.S. government was aware of the increasing numbers of illegal migrants crossing the border, Congress reduced funding for the Border Patrol, thereby decreasing efforts to prevent illegal migrants from entering the country. ${ }^{32}$ Finally, the U.S. government had no employer sanctions provisions to discourage U.S. employers from hiring undocumented workers. ${ }^{33}$

When the countries initially passed the treaty, and up until the expiration of the wartime provision in 1947, the U.S. government participated in the program in a supervisory role and as an aid to U.S. employers in their recruitment efforts. ${ }^{34}$ However, after 1947, the U.S. government adopted a laissez-faire approach to the Bracero Program and allowed employers to self-

Experiences 30 (Int'l Migration Branch of Int'l Labour Office, Working Paper No. 36, Sept. 2000), available

at http://www.ilo.org/public/english/protection/migrant/download/imp/imp36.pdf.

24. Id.

25. Otis L. Graham JR., UnguaRded Gates: A History of AMERICA's IMMigRation CRISIS 71 (2003) [hereinafter GRAHAM, UNGUARDED GATES].

26. Id.

27. Ryan D. Frei, Comment, Reforming U.S. Immigration Policy in an Era of Latin American Immigration: The Logic Inherent in Accommodating the Inevitable, 39 U. RICH. L. REV. 1355, 1369 (2005).

28. HNG, supra note 22, at 128. (noting "[a]ccording to the official statistics of the INS, apprehensions of deportable aliens averaged less than 10,000 per year from 1934 to 1943. From 1944 to 1954 apprehensions rose, averaging greater than 277,000 per year with a high of $1,089,538$ in 1954").

29. López, supra note 12 , at 667.

30. Id.

31. HivG, supra note 22, at 128 (citing (in part) Eleanor Hadley, A Critical Analysis of the Wetback Problem, 21 LT. CONTEMP. PROB. 334, 344 (1956)).

32. López, supra note 12 , at 668-69.

33. Id. at 669 .

34. HING, supra note 22, at 126. 
govern. $^{35}$ Though the Mexican government was disappointed with the choice of the U.S. government to abandon its supervisory role, it did not withdraw from the program because Mexican participation was necessary to ease the high rates of unemployment in Mexico. ${ }^{36}$

Despite its refusal to withdraw, the Mexican government wanted to discourage U.S. employers from undercutting the system by hiring illegal aliens; accordingly, it encouraged Mexican citizens to enter the United States legally. ${ }^{37}$ Mexico suggested the U.S. government should impose sanctions on employers who did not adhere to the program. ${ }^{38}$ In 1946, the Mexican Foreign Minister indicated the imposition of sanctions on employers who hired illegal immigrants would effectively end illegal migration. ${ }^{39}$ The Mexican suggestion was not completely discarded; the U.S. President's Commission on Migratory Labor made the same proposal in 1951 . $^{40}$ However, when the Immigration and Nationality Act of 1952 ("INA" or McCarren-Walter Act) ${ }^{41}$ was passed, it did not include a provision for employer sanctions. ${ }^{42}$ Rather than including the employer sanctions provision, Congress included the "Texas proviso," which imposed penalties for "the willful importation, transportation, or harboring of illegal aliens." the "normal practices incident to employment" would not constitute harboring. ${ }^{44}$ Though President Harry Truman vetoed the Act, Congress overrode Truman's veto and passed the Act without an employer sanctions provision. ${ }^{45}$ The defeat of the proposed employer sanctions provision has been attributed to resistance from politically powerful Southwestern employers and their supporters in the Senate and House of Representatives. ${ }^{46}$

Even though Congress refused to impose sanctions on employers in the INA, Congress dealt with illegal migration in a different way by passing the "Wetback Act" that same year. 47 "Operation Wetback" discouraged illegal migration in two ways: it imposed criminal sanctions on anyone caught smuggling or harboring immigrants who had not been inspected or legally

35. Id.

36. $I d$.

37. Martin \& Miller, supra note 23, at 30.

38. Id.

39. Id.

40. Id.

41. Immigration and Nationality Act of 1952 , ch. 477,66 Stat. 163 (current version at 8 U.S.C. $\$ 1324(2006))$.

42. Martin \& Miller, supra note 23 , at 30.

43. Id.

44. HING, supra note 22, at 30; Martin \& Miller, supra note 23, at 30; Michael Marinelli, Note, INS Enforcement of the Immigration Reform and Control Act of 1986: Employer Sanctions During the Citation Period, 37 CATH. U. L. Rev. 829, 830 n. 10 (1988).

45. GRAHAM, UNGUARDED GATES, supra note 25 , at 78-79.

46. HiNG, supra note 22 , at 130.

47. James F. Smith, A Nation that Welcomes Immigrants? An Historical Examination of United States Immigration Policy, 1 U.C. DAVIS J. INT'L \& POL'Y 227, 233 (1995) (citing Act of June 27,1952 , ch. 8,66 Stat. 163, 228-29 (1952), codified at 8 U.S.C. $\$ 1324$ (a) (1988)). 
admitted $^{48}$ and it allowed U.S. Border Patrol to pursue illegal migrants on private property within twenty-five miles of the border. ${ }^{49}$ Reports vary as to the actual number of illegal migrants deported under the Wetback Act, but the figures are significant. ${ }^{50}$

The juxtaposition of the 1952 INA and the Wetback Act appears to be conflicting policy, but legal scholars have suggested these policies represent the beginning of a shift in political power. ${ }^{51}$ The intense feelings of xenophobia by the public ${ }^{52}$ and the influence of Attorney General Herbert Brownell swayed Congress into confronting the illegal migration problem despite the resistance by large Southwestern employers. ${ }^{53}$ But employers were not all together swept aside; they still had the Bracero Program from which to draw inexpensive labor. ${ }^{54}$ The use of the Bracero Program increased dramatically in response to Operation Wetback; the number of workers entering under the Bracero Program increased from 200,000 in 1951 to 450,000 in $1956 .{ }^{55}$

Despite the increased use of the Bracero Program, there continued to be disapproval of employers hiring migrant workers. ${ }^{56}$ Organized labor argued that the presence of workers under the Bracero Program negatively influenced wages and working conditions. ${ }^{57}$ Government reports indicated that in regions where employers heavily used the Bracero Program, wages stagnated and were set by the Braceros. ${ }^{58}$ In response, President John F. Kennedy, through the Secretary of Labor, established a minimum wage rate ("adverse effect" rate) that applied to the employment of Braceros in each state in which they were employed. ${ }^{59}$ The intent behind the imposition of minimum wage rates was to prevent the previously lower Bracero wages from bringing down the pay rates for similarly -situated domestic workers. ${ }^{60}$

48. Kiera LoBreglio, Note, The Border Security and Immigration Improvement Act: A Modern Solution to a Historic Problem?, 78 ST. JoHN's L. REv. 933, 937 (2004).

49. JoAnne D. Spotts, U.S. Immigration Policy on the Southwest Border from Reagan Through Clinton, 1981-2001, 16 GEO. IMMIGR. L.J. 601, 605 (2002).

50. HING, supra note 22, at 130 ("over a million"); EYTAN MEYERS, INTERNATIONAL IMMIGRATION POLICY: A THEORETICAL AND COMPARATIVE ANALYSIS 40 (2004) ("over one million"); Spotts, supra note 49, at $605(300,000)$; LeBreglio, supra note 48, at $937(300,000)$.

51. See HiNG, supra note 22, at 130-31.

52. MEYERS, supra note 50 , at 40.

53. HiNG, supra note 22, at 130. Attorney General Herbert Brownell toured the border in 1953 and was shocked by its openness. HERBERT BROWNELL, wITH JOHN P. BURKE, ADVISING IKE: The MEMoIrs of ATTORNEY GENERAL HeRBERT BROWNELL (1993). Brownell is bestknown for his involvement in the civil rights movement, including his participation in the landmark case Brown v. Board of Education and his writing of the first draft of what would become the Civil Rights Act of 1957. Id.

54. HING, supra note 22, at 130.

55. Id.

56. Id.

57. Id.

58. Id. at 131

59. Id. at 130-31.

60. Id. at 131 . 
The discord with the program did not affect the commitment of the U.S. government to keep it alive. ${ }^{61}$ In 1954, after negotiations with Mexico to renew the Bracero Treaty failed, the United States decided to continue the program unilaterally despite opposition from the Mexican government. ${ }^{62}$

The Bracero Program continued until Congress allowed it to expire in $1964 .^{63}$ Scholars have cited many reasons as the cause of the end of the program. ${ }^{64}$ Some assert public awareness of appalling working conditions coupled with the Kennedy Administration's focus on civil rights brought about the end. ${ }^{65}$ Another reason cited for the termination of the program was increased opposition by labor unions and civil rights groups. ${ }^{66}$ Some blame a reduction in demand for Braceros due to increased mechanization in cotton and sugar beet production along with intensified enforcement of program rules, including increased minimum wage rates. ${ }^{67}$ Each of these factors may have played a role in the decision by Congress to discontinue the program.

Employers did not passively stand by as Congress eliminated their main source of labor. ${ }^{68}$ Employers pushed Congress to allow Mexican workers temporary alien worker status under the 1952 INA. ${ }^{69}$ Though the employers were politically powerful and had the support of several members of Congress, the efforts of employers were fruitless and Congress denied issuance of temporary alien worker status to Mexican workers. ${ }^{70}$

The end of the Bracero Program is significant because it signaled the end of legal migrant labor from Mexico. ${ }^{71}$ When the program ended in 1964, the workers were supposed to return to Mexico, but many workers did not leave. ${ }^{72}$ Those who remained in the United States automatically changed from legal migrant status to illegal migrant status. ${ }^{73}$ Employers, who had depended on the Bracero Program for most of their workforce, now turned to illegal migrants to fill their need for cheap labor without fear of punishment, because Congress had never imposed employer sanctions. ${ }^{74}$ Perhaps in spite of the U.S. policy, the Mexican government chose this time to abandon its former official

61. Smith, supra note 47 , at 244 .

62. Id.

63. HING, supra note 22, at 131.

64. HING, supra note 22, at 131; Kitty Calavita, U.S. Immigration Policy: Contradictions and Projections for the Future, 2 Ind. J. Global Legal Stud. 143, 146 (1994); Spotts, supra note 49, at 605; see also LoBreglio, supra note 48, at 937.

65. Calavita, supra note 64 , at 146.

66. Spotts, supra note 49, at 605; see also LoBreglio, supra note 48, at 937.

67. HING, supra note 22 , at 131 .

68. Id.

69. Id.

70. Id.

71. See id.

72. Spotts, supra note 49 , at 606.

73. Id.

74. HING, supra note 22 , at 131 ; Calavita, supra note 64 , at 146. 
opposition to its citizens working in the United States. ${ }^{75}$ The Mexican government understood its citizens were spending the money earned in the United States in Mexico. ${ }^{76}$

The end of the Bracero Program coincided with an important change in immigration policy. ${ }^{77}$ By the middle of the 1960 s, the Civil Rights Movement was in full swing in the United States. ${ }^{78}$ As part of this movement away from racist ideologies, President Kennedy sent a message to Congress in 1963 asking for changes in the immigration policy. ${ }^{79}$ Kennedy wanted Congress to abolish the policies that "discriminate among applicants for admission into the U.S. on the basis of the accident of birth." 80 Kennedy thought the National Origin quota was arbitrary and not based on logic or reason. ${ }^{81}$ In 1964, Congress passed $^{82}$ the Civil Rights Act, ${ }^{83}$ which specifically prohibited discrimination on the "basis of race, creed, religion, sex, or "national origin.",84

In legislative debates concerning immigration reform, legislators expressed concern that basing immigration admission on national origin was discriminatory, unfair, and contradictory to the United States' policy of equality as codified in the Civil Rights Act. ${ }^{85}$ Though a few legislators made the same arguments that had been made in support of the quota system, namely that Anglo-Saxon immigrants assimilate better than other immigrants, these legislators did not have the support of the public or organized labor like their predecessors. ${ }^{86}$ In fact, most of the American public was either unaware or indifferent to immigration policy changes, and organized labor was no longer concerned about immigrants infiltrating the workforce. ${ }^{87}$ The only real resistance came from patriotic societies with concerns about communists and subversives, but these societies were willing to compromise on the quota system upon condition that the numbers of legally-entering immigrants did not substantially change. ${ }^{88}$ They were also assuaged by the fact that the proposed preference system would allow immediate relatives admission priority and that likely meant the racial-ethnic composition of the country would probably

75. Spotts, supra note 49 , at 606 .

76. Id.

77. Immigration and Nationality Act of 1965, Pub. L. No. 89-236, 79 Stat. 911 (codified as amended at 8 U.S.C. $\$ 1151(2000)$ ).

78. See Fuchs, supra note 18, at 435.

79. GRAHAM, UNGUARDED GATES, supra note $25,87-88$.

80. Id. at 88 .

81. Id.

82. GRAHAM, UNGUARDED GATES, supra note 25 , at 88.

83. Civil Rights Act 1964, Pub. L. No. 88-352, 78 Stat. 241 (1964) (codified as amended at 42 U.S.C. $\S \S 2000-2000 \mathrm{~h}(2000)$ ).

84. Id. at 88-89 (emphasis in original).

85. See id. at 89 .

86. $I d$. at 90 .

87. Id. at $90-91$.

88. Id. 
remain unchanged. $^{89}$

Congress thus amended the INA, by enacting the Immigration and Nationality Act of 1965 (hereinafter "1965 INA"), which abolished the inherently racist National Origins quota system and increased legal immigration from the Eastern Hemisphere. ${ }^{91}$ Congress replaced the quota system with a system placing a per-country limit on the number of persons who could gain lawful entry each year. ${ }^{92}$ Immigration from the Eastern Hemisphere was limited to 160,000 total immigrants with a limit of 20,000 immigrants per country. ${ }^{93}$ Entry was granted to persons from the Eastern Hemisphere based on a preference system in which those individuals with family already living in the United States, skilled labor, and refugees were given priority over other immigrants. ${ }^{94}$ The 1965 INA also set limits on immigration from within the Western Hemisphere, which were to take effect in $1968 .^{95}$ Immigration from Western Hemisphere countries was also limited to 20,000 people per country, with 120,000 per year for the entire hemisphere; however, admission of immigrants from this region was not based on the preference system. ${ }^{96}$

Placing caps on Western Hemisphere immigration was not initially part of the system, but Congress later added caps to appease congressional leaders who opposed ending the National Origins system. ${ }^{97}$ Proponents of the bill had difficulty arguing the National Origins system was discriminatory and should be eliminated while simultaneously supporting a bill that gave preference to people from certain regions of the world. ${ }^{98}$ Employers, who had relied on the cheap Mexican labor, did not oppose the bill as strongly as they had opposed previous government attempts to interfere with their labor supply. ${ }^{99}$ The labor needs of employers could be satiated by entirely different sources; "the baby boom was pouring new workers into the economy" and, with the passing of the Civil Rights Act, millions of underemployed black workers would be looking for employment. ${ }^{100}$ Additionally, the large Southwestern agricultural employers did not dissent, because civil rights groups, religious groups, and organized

89. Id. at 91 .

90. Frei supra note 27, at 1371 (citing Immigration and Nationality Act of 1965, Pub. L. No. 89-236, 79 Stat. 911 (codified as amended at 8 U.S.C. $\$ 1151(2000)$ )).

91. See Catherine E. Halliday, Note, Inheriting the Storied Pomp of Ancient Lands: An Analysis of the Application of Federal Immigration Law on the United States' Northern and Southern Borders, 36 VAL. U. L. REV. 181, 196 (2001).

92. Smith, supra note 47 , at 234.

93. Id.

94. Hugh Davis Graham, Colusion Course: The Strange Convergence of AFFIRMATIVE ACTION AND IMMIGRATION POLICY IN AMERICA 59-64 (2002) [hereinafter GRAHAM, COLLISION COURSE].

95. MEYER , supra note 50, at 43.

96. Graham, Collision COURSE, supra note 94, at 62.

97. Id. at 61-62.

98. Id. at 62 .

99. Id. at 63 .

100. Id. 
labor had aggressively attacked them for employment practices regarding foreign workers. Those employers were also aware that there would be an ample supply of illegal migrants existed to fill their labor needs. ${ }^{101}$

The change in immigration policy was significant for two reasons. ${ }^{102}$ It was the first time in history the United States had imposed a ceiling on Mexican immigration ${ }^{103}$ and effectively ended the open-door (or "Good Neighbor") policy of immigration from Mexico. ${ }^{104}$ This led to huge increases in illegal migration, because the factors motivating Mexicans to migrate were still pertinent. ${ }^{105}$ Second, the 1965 INA signified a huge unanticipated change in U.S. immigration policy. ${ }^{106}$ By removing the strict quota system and placing a priority on family reunification, the 1965 INA was the first step in the liberalization of U.S. immigration policy. ${ }^{107}$ " [T] he 1965 law, and subsequent policy, shifted the nation from a population-stabilization to a population-growth path ...."108 The liberalization of the United States' immigration policies coupled with huge increases in illegal migration from Mexico forced the U.S. government to redirect its focus from preventing illegal migrants from entering the United States to dealing with illegal migrants after they had already entered the country. ${ }^{109}$

The 1965 INA policies created waiting periods as long as two-and-a-half years for Mexicans seeking visas for legal entry into the United States, ${ }^{110}$ resulting in an increase in illegal border crossings. ${ }^{111}$ In response, President Jimmy Carter proposed substantial immigration policy changes to Congress in $1977,{ }^{112}$ which included instituting employer sanctions, increasing the limit of immigrants allowed from Mexico, and granting temporary amnesty to Mexicans who had been in the United States illegally for over five years, as well as other changes. ${ }^{113}$ Opponents of the employer sanctions proposal resisted because sanctions would increase the potential for discrimination against ethnic minorities and would impose an excessive burden on employers. ${ }^{114}$ The

101. Id.

102. GRAHAM, UNGUARDED GATES, supra note 25, at 96; LoBreglio supra note 48, at 938 .

103. LoBreglio supra note 48 , at 938.

104. Smith, supra note 47 , at 234.

105. Id. at 235; Spotts, supra note 49, at 607; see also LoBreglio, supra note 48, at 938.

106. GRAHAM, UNGUARDED GATES, supra note 25 , at 96.

107. Id.

108. Id.

109. Smith, supra note 47 , at 235 ; Spotts, supra note 49,607 .

110. Spotts, supra note 49 , at 606-07.

111. Id. at 607.

112. Id.; See also Cecilia M. Espenoza, The Illusory Provisions of Sanctions: The Immigration Reform and Control Act of 1986, 8 GEo. IMMIGR. L.J. 343, 359-60 (1994).

113. Spotts, supra note 49, at 607 (citing David M. Heer, Undocumented Mexicans in the United States 155 (1990)).

114. Marinelli, supra note 44, at 832 (citing H.R. Rep. No. 108, 93d Cong., 1st Sess. 5 (1973)); see also Martin \& Miller, supra note 23, at 30 (Stating that the 1984 Democratic presidential candidates campaigned against employer sanctions on the ground that they would increase labor market discrimination.). 
changes suggested by the President were not initially adopted, possibly because of the opposition. ${ }^{115}$ Notably, the following year, Congress eliminated its country-specific limits and replaced country-specific limits with a worldwide limit. ${ }^{116}$ Also, in 1978, Congress created the Select Committee on Immigration and Refugee Policy (SCIRP) to study existing immigration policy and to make recommendations for improvements. ${ }^{117}$

After two years of investigating the current system, collecting public opinion, and trying to balance the requirements of efficiency, fairness, due process protections, and humanitarian concerns, ${ }^{118}$ SCIRP made over 100 recommendations to President Ronald Reagan and Congressional leaders on March 1, 1981. ${ }^{119}$ One of the primary recommendations, inter alia, made by SCIRP was the imposition of sanctions on employers who knowingly hired illegal aliens. ${ }^{120}$ In its report, SCIRP stated:

Without an enforcement tool to make the hiring of undocumented workers unprofitable, efforts to prevent the participation of undocumented / illegal aliens in the labor market will continue to meet with failure. Indeed, the absence of such a law serves as an enticement for foreign workers. The Commission, therefore, believes some form of employer sanctions is necessary if illegal migration is to be curtailed. ${ }^{121}$

In order for employer sanctions to be effective, SCIRP also recommended the creation of a reliable means of verifying employment eligibility. ${ }^{122}$ SCIRP had two related concerns regarding verification: preventing discrimination by employers and avoiding substantial burdens for employers. ${ }^{123}$ Though disagreement existed within the Commission as to how to address these concerns, a faction of SCIRP supported the creation of a new employee identification system that was more secure than anything in existence at that

115. Marinelli, supra note 44 , at 832 .

116. Spotts, supra note 49 , at 607 (citing Heer, supra note 113, at 13).

117. Frei, supra note 27, at 1372 (citing David M. Turoff, Note, Illegal Aliens: Can Monetary Damages be Recovered from Countries of Origin Under an Exception to the Foreign Sovereign Immunities Act?, 28 Brook. J. Int'l L. 179, 183 (2002); Fuchs, supra note 18, at 43637 (citing Act of Oct. 5, 1978, Pub. L. No. 95-412, 92 Stat. 908 (1978)); Spotts, supra note 49, at 607 (citing Heer, supra note 113, at 195).

118. Fuchs, supra note 18, at 438.

119. Id.; Espenoza, supra note 112, at 360; Spotts, supra note 49, at 608 .

120. Martin \& Miller, supra note 23, at 30; Frei, supra note 27, at 1372; Fuchs, supra note 18, at 439; Spotts, supra note 49, at 607 (citing Heer, supra note 113, at 155).

121. Espenoza, supra note 112 , at 346 n.23 (quoting U.S. Immigration Policy and the National Interest: The Final Report and Recommendations of the Select Commission on Immigration and Refugee Policy to the Congress and the President of the United States 62 (1981)).

122. Fuchs, supra note 18 , at $439-40$.

123. Id. at 439 . 
time. ${ }^{124}$ "Commissioners ... [felt] that it would be less discriminatory than a system based on existing forms of identification and even would produce less discrimination than currently exist[ed] in the absence of an employer sanctions law." 125

Due to the SCIRP recommendations, President Reagan formed a task force to examine current immigration policy and generate plausible reform proposals to recommend to Congress. ${ }^{26}$ The task force was unsuccessful in creating concrete recommendations. ${ }^{127}$ However, after several meetings with his Cabinet, Reagan's recommendations to Congress included imposing sanctions, in the form of civil fines, on employers who hire illegal workers and the creation of a worker eligibility verification system. ${ }^{128}$ The Department of Justice and the Attorney General made the same recommendations to Congress. ${ }^{129}$

In March of 1982, a full year after the SCIRP recommendations were presented, Representative Romano L. Mazzoli (D-KY) and Senator Alan K. Simpson ${ }^{130}$ (R-WY) sponsored an immigration reform bill, the Immigration Reform and Control Act (IRCA), which incorporated some of the earlier recommendations including employer sanctions. ${ }^{131}$ Supporters of the sanctions provisions asserted that the sanctions would serve several purposes, including eliminating the temptation of American jobs for illegal workers ${ }^{132}$ and the reduction of costs associated with border enforcement, because employers would act as de facto agents of the Immigration and Naturalization Service (INS). ${ }^{133}$ The bill quickly passed in the Senate but stalled in the House. ${ }^{134}$ The IRCA eventually passed in the House and President Reagan signed the bill into law in 1986, creating the first employer sanctions provisions in the United States. ${ }^{135}$

124. $I d$.

125. Id. (citing Select Comm'N ON IMMIGRATION AND Refugee Policy, 97TH CONG., 1ST SESS., FinAL REPORT AND RECOMMENDATIONS (1981)).

126. Spotts, supra note 49 , at 608 (citing NiCHOlas LaHAM, RoNALD REAGAN AND THE POLITICS OF IMMIGRATION REFORM 6 (2000)).

127. Spotts, supra note 49 , at 609 (citing LAHAM, supra note 126 , at 124).

128. Id. (citing LAHAM, supra note 126, at 107).

129. Id. (citing LAHAM, supra note 126 , at 107 ).

130. Senator Simpson was a member of SCIRP and Chairman of the Senate Immigration Subcommittee. Id. at 608 .

131. Espenoza, supra note 112, at 360; Spotts, supra note 49, at 609.

132. Espenoza, supra note 112, at 360 (citing Options for an Improved Employment Verification System, a Staff Report, prepared for the Use of the Subcomm. on Immigration and Refugee Affairs of the Comm. on the Senate Judiciary, 102d Cong., 2d Sess. 1-2 (1992)).

133. Espenoza, supra note 112, at 360 (citing Confirmation Hearing of Attorney General Designate Zoe Baird as Attomey General Before the Senate Judiciary Comm., 103d Cong., 1st Sess. (1993) (statement of Sen. Heflin (R-AL)), available in LEXIS, News Library, Script File).

134. Spotts, supra note 49 , at 609 .

135. Id.; 8 U.S.C.A. $§ 1324$ (2006). 


\section{B. United Kingdom}

The United Kingdom does not have the same long, rich history of employer sanctions found in the United States. ${ }^{136}$ The United Kingdom did not even debate employer sanctions until the late 1970s when the European Community began pressuring the U.K. about the issue. ${ }^{137}$ During that period, the international community "generally supported the introduction of sanctions, believing that, by minimizing illegal immigration, the status and legitimacy of authorized migrants would be improved." ${ }^{138}$ International organizations, like the International Labour Office (ILO), ${ }^{139}$ supported the theory, which focused on the importance of including employer sanctions as "an integral part of effective migration management." "140 The ILO approved a Convention in 1975, which included provisions requiring countries to create systems of detection and both civil and criminal punishment for illegal employment of migrant workers. ${ }^{141}$ The following year, the European Commission proposed a similar directive, which after amended in 1978, required European Union (EU) Member States to enact laws sanctioning employers of illegal migrant workers. ${ }^{142}$ The British government resisted the draft directive within the EU Council of Ministers, specifically because of the employer sanctions provision. $^{143}$

This international push toward adopting employer sanctions coincided with President Carter's introduction of proposals supporting the imposition of employer sanctions in the United States. ${ }^{144}$ But at this particular point in time, neither the United States nor the United Kingdom chose to follow the trend of adopting employer sanctions. ${ }^{145}$

The reasons for British opposition to employer sanctions were similar to

136. See supra Part П(A).

137. Bernard Ryan, The Evolving Legal Regime on Unauthorized Work by Migrants in Britain, 27 COMP. LAB. L. \& POL'Y J. 27, 35 (2005) [hereinafter Ryan 2005].

138. Martin \& Miller, supra note 23, at 4.

139. PICUM, supra note 1 , at 23.

The [ILO] was established in 1919 to elaborate, promote and monitor implementation of international standards regarding treatment of labour [sic]; to provide orientation and technical assistance to its tripartite constituents; and to address contemporary issues affecting workers, employers and governments worldwide. ILO is a specialized agency of the United Nations system; it is unique in having civil society participation in its governance through its tri-partite structure in which representatives of national employer and worker organizations participate alongside representatives of government.

Id.

140. Martin \& Miller, supra note 23, at 4.

141. Id. (citing ILO Convention 143, Article 6, 1 (Dec. 9, 1978)).

142. Martin \& Miller, supra note 21, at 4; Ryan 2005, supra note 137, at 35.

143. Ryan 2005 , supra note 137 , at 35 .

144. Spotts, supra note 49, at 607 ; see also Espenoza, supra note 112, at 359-60; see supra notes 112-115 and accompanying text.

145. Ryan 2005, supra note 137, at 35; Spotts, supra note 49, at 607 . 
the reasons given by opponents in the United States. ${ }^{146}$ Fears that sanctions would encourage discrimination against ethnic minorities by potential employers and excessively burden employers who complied with the sanctions were common arguments by opposition in both the United States ${ }^{147}$ and the United Kingdom. ${ }^{148}$ One argument unique to the United Kingdom was that its position as an island puts it in a geographically distinct position ${ }^{149}$ effectively allowing it to control immigration simply by controlling its ports of entry, thereby reducing the possibility that illegal migrants could enter the country and eliminating the need for after-entry enforcement efforts. ${ }^{150}$

At this point in history, the paths of the United Kingdom and the United States to the imposition of employer sanctions diverged. ${ }^{151}$ While the United States formed a committee to study the issue, ${ }^{152}$ the United Kingdom abandoned the idea of employer sanctions until the 1990 s. ${ }^{153}$ Scholars attribute silence on the issue to forces shaping economic migration, specifically the labor demands of the U.K. market. ${ }^{154}$ The economy of the United Kingdom was flat in the $1970 \mathrm{~s}$ and $1980 \mathrm{~s}$, and thus there was little to no demand for migrant labor. ${ }^{155}$ This changed in the late 1980 s when deregulation policies created a new business sector specifically catering to the growing global market. ${ }^{156}$ Globalization affected the service and manufacturing sectors as well; the demand for goods and services increased to fulfill the growing needs of the global market, and at the same time, globalization forced U.K. businesses in these sectors to compete with companies from around the world. ${ }^{157}$ In order to keep up with the competition, U.K. employers needed a low-cost, somewhatexpendable workforce. ${ }^{158}$ The creation of the global economy and increased

146. See supra note 114 and accompanying text.

147. $I d$.

148. Ryan 2005, supra note $137,35-36$.

149. Bernard Ryan, Recent Legislation, Employer Enforcement of Immigration Law after Section Eight of the Asylum and Immigration Act 1996, 26 INDUS. L.J. 136, 147 (1997) [hereinafter Ryan 1997] ("The UK's island geography enables us to operate effective frontier controls, concentrated on a small number of ports and airports. Because of this, our overall system of immigration control has correspondingly less need for in-country enforcement.") (quoting Home Affairs Committee, Migration Control at the External Borders of the European Community, 1991-92 HC Papers 215, at 66-67). Whereas the United States shares a land border with Mexico, the origin of the majority of illegal migrants in the United States. See supra note 21 and accompanying text..

150. Ryan 2005, supra note 137, at 35-36.

151. Ryan 1997, supra note 149 , at 147; see supra note 116 and accompanying text.

152. Frei, supra note 27 , at 1372; Fuchs, supra note 18, at 436-37; Spotts, supra note 49 , at 607 (citing HEER, supra note 113, at 195).

153. Ryan 1997, supra note 149 , at 147.

154. Donn Flynn, An Historical Note on Labour Migration Policy in the UK 4, in LABOUR MigRATION AND EMPLOYMENT RIGHTS (Bernard Ryan ed., 2005).

155. Id. at 3-4.

156. Id. at 4 .

157. Id.

158. Id. 
demand for labor coincided with an increase in refugees resulting from political upheaval in other parts of Europe. ${ }^{159}$ This combination of factors set the stage for a dramatic increase in the number of illegal migrants entering the United Kingdom and finding illegal employment. ${ }^{160}$ For example, "the Immigration Service detected only 4,000 persons engaged in illegal work in 1988, but that by 1994 this had risen to 10,000 . That figure moreover represented 'only a small proportion of the total number working in the United Kingdom illegally."

At about the same time, there were other pressures, both internal and external, on the United Kingdom. ${ }^{162}$ The government expressed concern that the United Kingdom was "seen as a soft target in Western Europe" for illegal migrants seeking employment, because it was one of the only countries in the EU to not have employer sanctions provisions. ${ }^{163}$ In 1995 , the EU Member States agreed to a French proposal on European harmonization on the issue of employment of illegal migrants, which called for the adoption by Member States of "criminal and/or administrative penalties" for employers of illegal migrants. ${ }^{164}$ The United Kingdom officially adopted the French recommendation in September 1996. ${ }^{165}$

Though the British government did not specifically refer to the harmonization recommendation, the culmination of these forces led to the enactment of the Asylum and Immigration Appeals Act of $1996,{ }^{166}$ which contained the United Kingdom's first employer sanctions provision. ${ }^{167}$

\section{EMPLOYER SANCTIONS LEGISLATION}

\section{A. Relevant Provisions}

\section{United States}

The IRCA has three interrelated provisions relevant to this Note:

159. Id. Such political upheaval included an armed conflict in southeastern Europe and the collapse of the Soviet Union. Id.

160. Ryan 1997, supra note 149 , at 146.

161. Id. (citing Consultation Document, II. 3).

162. Id. at 147 .

163. Id.

164. Id.

165. Id.

166. Asylum and Immigration Appeals Act, 1996, c. 49. (The Asylum and Immigration Appeals Act 1993 was also passed, but it did not specifically deal with the employment of illegal migrants, and as such is outside of the scope of this Note. Flynn, supra note 154, at 5.)

167. Ryan 1997, supra note 149, at 147 (citing Asylum and Immigration Appeals Act, 1996$, c. $49, \S 8)$. 
employer sanctions for knowingly employing undocumented workers, ${ }^{168}$ an anti-discrimination provision, ${ }^{169}$ and a provision that authorizes the President to establish a new worker verification system. ${ }^{170}$ The employer sanctions provisions make it unlawful: (1) to knowingly hire or continue to employ an illegal alien and (2) to hire an employee without verifying his or her employment eligibility. ${ }^{171}$ Knowing not only means actual knowledge, but also includes constructive knowledge, which the statute defines as "knowledge which may fairly be inferred through notice of certain facts and circumstances which would lead a person, through the exercise of reasonable care, to know about a certain condition." 172 Both of these offenses subject an employer to civil fines (sanctions), unless the employer is found to have engaged in a pattern of hiring illegal workers, which will subject the employer to criminal penalties including six months imprisonment. ${ }^{173}$ The statute defines "pattern" as "regular, repeated, and intentional activities." "174 Generally, an employer can escape liability by showing compliance with the verification procedure. ${ }^{175}$ The employment eligibility verification requirement mandates employers fill out an Employment Eligibility Verification Form, or I-9 form, for each new employee hired. This process includes the inspection of a new employee's documentation to establish identity and authorization to work, the employer signing and attesting that they have inspected the documents, and the employee signing and attesting that he or she is eligible to work in the United States. ${ }^{176}$ If an employer demonstrates the documents reasonably appeared genuine, then the employer has established an affirmative good faith defense relieving the employer of any potential liability for sanctions. ${ }^{177}$ The government can rebut the good faith presumption upon "evidence that the documents did not reasonably appear to be facially valid, that the employer and employee colluded to avoid the requirements of the [IRCA], or that the verification procedure was a sham." I78 Initially, the IRCA allowed new employees to present any of twenty-nine different documents to prove eligibility and identity. ${ }^{179}$ Currently,

168. 8 U.S.C. $\& 1324 \mathrm{a}(\mathrm{a})$ (2006).

169. 8 U.S.C. $\S 1324 b$.

170. 8 U.S.C. $\& 1324 \mathrm{a}(\mathrm{d})(1)$.

171. Espenoza, supra note 112 , at 360-61; Smith, supra note 47 , at 236-37; Martin \& Miller, supra note 23 , at 31 .

172. 8 C.F.R. § 1247a.1(1)(1) (2006). See Martha J. Schoonover et al., American Law Institute-American Bar Association Continuing Legal Education, Employment Authorization Regulations and I-9 Compliance, SL010 A.L.I.-A.B.A. 9, 29 (2006).

173. 8 U.S.C. $\$ 1324 \mathrm{a}(\mathrm{f})(1)(2006)$.

174. 8 C.F.R. $\$ 1247$ a.1(k) (2006).

175. Marinelli, supra note 44 , at 837.

176. Espenoza, supra note 112 , at 361 .

177. 8 U.S.C. $\$ 1324 \mathrm{a}(\mathrm{b})(1) \&(6)$.

178. Marinelli, supra note 44 , at 837 (citing H.P. REP. No. 99-682, pt. 1, at 57, reprinted in 1986 U.S. CODE CONG. \& ADMIN. NEws 5649, 5661).

179. Martin \& Miller, supra note 23, at 37. 
fifteen acceptable forms of documentation exist. ${ }^{180}$ Other than the types of acceptable forms of documentation, the employer sanctions provisions and the employment eligibility verification system laid out in the IRCA have generally remained unchanged since $1986 .^{181}$

A major concern when the IRCA was passed was that the threat of employer sanctions would lead employers to discriminate against individuals seeking work on the basis of appearance. ${ }^{182}$ As an effort to prevent this, the IRCA included an anti-discrimination provision. ${ }^{183}$ The provision stipulates employers are required to ask all new hires for the same types of documentation and may not ask questions regarding an individual's place of origin. ${ }^{184}$ Employers who discriminate in hiring, recruiting, or firing on the basis of national origin or citizenship status for individuals who are either citizens or are legally in the United States have committed an "unfair immigration-related employment practice." ${ }^{185}$ The Act also created an Office of Special Counsel for Immigration Related Employment Practices in the Department of Justice to enforce the anti-discrimination provisions. ${ }^{186}$ If the Special Counsel finds an employer has violated the anti-discrimination provisions, he may order the employer to cease and desist from further discrimination, to hire the discriminated-against individual with backpay, to pay a civil fine, and to keep records of all job applicants the employer has denied employment and make this available to the Special Counsel. ${ }^{187}$

\section{United Kingdom}

The employer sanction provision of the Asylum and Immigration Appeals Act 1996, better known as Section 8, created the criminal offense of employing anyone who is subject to immigration control unless the employee is otherwise eligible for employment. ${ }^{188}$ Those individuals subject to immigration control, but otherwise eligible for employment, generally fall into one of two categories:

180. Jeffery L. Ehrenpreis, Controlling Our Borders Through Enhanced Employer Sanctions, 79 S. CAL. L. REV. 1203, 1207-08 (2006) (citing 8 C.F.R. § 1274a.2(b)(1)(v) (2006)).

181. General Accounting Office, Immigration Enforcement: Weaknesses Hinder Employment Verification and Worksite Enforcement Efforts, 1, GAO-06-895T, June 19, 2006, available at http://www.gao.gov/new.items/d06895t.pdf [hereinafter GAO, Immigration Enforcement: Weaknesses].

182. See supra Part $\mathrm{I}(\mathrm{A})$.

183. 8 U.S.C. $\S 1324 b(a)(2006)$.

184. Martin \& Miller, supra note 23 , at 35 .

185. 8 U.S.C. $\S 1324 \mathrm{~b}(\mathrm{a})(1)$; see also Espenoza, supra note 112, at 364-68; Marinelli, supra note 44, at 837-38; Martin \& Miller, supra note 23, at 35-36.

186. Marinelli, supra note 44, at 846; Martin \& Miller, supra note 23, at 35.

187. Marinelli, supra note 44 , at 846 (citing 8 U.S.C. $\$ 1324 b(g)(2)(B)(i v)$ ) (2006) (the penalty for a first offense is no more than $\$ 1000$ and the penalty for a second offense is $\$ 2000$ ); Martin \& Miller, supra note 23, at 35-36.

188. HoMe OfFICE, COMPREHENSIVE GUIDANCE FOR UNITED KINGDOM EMPLOYERS ON Changes to the LaW on PREventing ILlegal Working, 2004, at 3 [hereinafter Home OfFice, COMPREHENSIVE 2004]; see Ryan 2005, supra note 137, at 36. 
they have been given valid and continuing permission to remain in the United Kingdom and are not restricted from accepting a position in their current employment field or the person falls into an immigration category in which employment is permitted. ${ }^{189}$ Employers convicted of violating Section 8 are subject to fines up to $£ 5000$ (about $\$ 9,916.70$ ) ${ }^{190}$ per illegal employee. ${ }^{191}$

Section 8 also created a statutory defense for employers. ${ }^{192}$ This defense allows employers to circumvent penalties by verifying the documentation papers of a potential employee appear "to relate to the employee" prior to hiring him or her and retaining a copy of the documentation. ${ }^{193}$ A list of thirteen acceptable documents was set out in secondary legislation. ${ }^{194}$ Initially, employers could accept evidence of National Insurance numbers, ${ }^{195}$ British birth certificates, or a number of other forms of identification that do not contain a picture of the beholder. ${ }^{196}$ Later, the list was modified by the Nationality, Immigration and Asylum Act 2002, which amended Section 8 to require employers to check more than one document if the document being proffered does not include a picture of the job candidate. ${ }^{197}$ However, the defense is not available for employers who knowingly hire illegal workers, even if the employer retains copies of the worker's documentation. 198 "Knowingly" is defined as actual knowledge. ${ }^{199}$

In passing Section 8, the government changed its long-standing policy and found itself confronting the same concerns it had dealt with in the 1970s when Congress originally rejected employer sanctions. ${ }^{200}$ Opponents of

189. HOME OFFICE, COMPREHENSIVE 2004, supra note 188 , at 3.

190. As of June 2, 2008. GoCurrency.com, Currency Converter, http://www.gocurrency.com (last visited June 2, 2008).

191. HOME OFFICE, COMPREHENSIVE 2004, supra note 188 at 5; Asylum and Immigration Appeals Act, 1996, c. 49, § 8(4); Ryan 2005, supra note 137, at 41; Ryan 1997, supra note 149, at 137.

192. Asylum and Immigration Appeals Act, 1996, c. 49, § 8(2).

193. Id.

194. Ryan 1997, supra note 149, at 139-140 (citing Immigration (Restrictions on Employment) Order, 1996, S.I. 1996/3325).

195. The National Insurance number is similar to a Social Security number in the United States because contributions collected under the National Insurance system go toward benefits. Nic Cicutti, National Insurance, MSN UK MONEY, May 16, 2005, http://money.uk.msn.com/tax/taxguide/article.aspx?cp-documentid=4753989. The types of benefits provided for by National Insurance Contributions include: retirement pensions, sickness, unemployment, maternity, and widows' pensions. Id. United Kingdom residents under the age of sixteen are automatically issued National Insurance numbers, whereas noncitizens have to apply for them. HM Revenue \& Customs, Your National Insurance Number, at http://www.hmrc.gov.uk/faqs/ynino.htm (last visited June 2, 2008).

196. Ryan 1997, supra note 149, at 139-40; Ryan 2005, supra note 137 , at 48 .

197. Ryan 2005, supra note 137, at 39 (citing Immigration (Restrictions on Employment) Order, 2004, S.I. 2004/755).

198. Asylum and Immigration Appeals Act, 1996, c. 49, § 8(3).

199. IMMIGRATION AND NATIONALITY DIRECTORATE, OPERATION MANUAL $\$ 55.4 .1$ (2006) [hereinafter IND, OPERATION MANUAL].

200. See supra Part II(B). 
employer sanctions feared sanctions would increase the likelihood employers would discriminate against ethnic minorities when making hiring decisions to avoid the possibility of liability under the provision. ${ }^{201}$ In an effort to prevent discrimination, the government released a parallel report with the legislation providing guidance for employers regarding how to comply with the new law without violating pre-existing anti-discrimination law, the Race Relations Act 1976 (and the Race Relations Order 1997 in Northern Ireland). ${ }^{202}$ The Race Relations Act 1976 "prohibits discrimination against applicants on grounds of 'colour [sic], race, nationality or ethnic or national origin.",203

\section{Distinguishing the IRCA from Section 8}

Although the provisions of the IRCA and Section 8 appear similar at first glance, some important differences exist. Both subject employers to civil sanctions for knowingly hiring individuals who are unauthorized to work due to immigration violations. ${ }^{204}$ Both also include a statutory defense for employers who attempt to preempt violations by verifying an employee's employment eligibility documentation. ${ }^{205}$ Despite these similarities, the legislation of the two countries is different in three important respects: the standard by which the countries define knowledge, ${ }^{206}$ employment eligibility verification requirements, ${ }^{207}$ and anti-discrimination provisions. ${ }^{208}$

The knowledge element in the United Kingdom is a subjective standard of actual knowledge; ${ }^{209}$ whereas, in the United States, the knowledge requirement also includes constructive knowledge. ${ }^{210}$ In the United States, knowing not only means actual knowledge "but also knowledge which may fairly be inferred through notice of certain facts and circumstances which would lead a person, through the exercise of reasonable care, to know about a certain condition."211 In the United Kingdom, knowledge requires that the defendant

201. Dallal Stevens, Legislation, The Asylum and Immigration Act 1996: Erosion of the Right to Seek Asylum, 61 MoD. L. REV. 207, 217-18 (1998).

202. HOME OFFICE, COMPREHENSIVE 2004, supra note 188, at 6.

203. Ryan 1997, supra note 149 , at 141-42.

204. Compare 8 U.S.C. $\$ 1324 \mathrm{a}(\mathrm{a})$ (2006), with Asylum and Immigration Appeals Act, 1996 , c. $49, \S 8(1)$.

205. Compare 8 U.S.C. $\S 1324 a(b)(1)$, with Asylum and Immigration Appeals Act, 1996, c. $49, \S 8(2)$.

206. Compare 8 C.F.R. $\$ 1247$ a.1(1)(1) (2006), with IND, OPERATION MANUAL, supra note 199, at \$ 55.4.1. See Winnie Chan \& A.P. Simester, Intention Thus Far, CRIM. L. REV. 1997, OCT, 704, 716 (indicating " $[\mathrm{k}]$ nowledge requires a positive (and correct) belief on the part of the defendant that the relevant circumstance does indeed exist").

207. Compare 8 U.S.C. $\$ 1324 \mathrm{a}(\mathrm{b})(2)$, with Asylum and Immigration Appeals Act, 1996, c. $49, \S 8(2)$.

208. Compare 8 U.S.C. $\S 1324$ b, with HOME OFFICE, COMPREHENSIVE 2004, supra note 188 , at 6 .

209. IND, OPERATION MANUAL, supra note 199 , at $\$ 55.4 .1$.

210. 8 C.F.R. \$ 1247a.1(1)(1) (2006); see Schoonover et al., supra note 172, at 29.

211. 8 C.F.R. \$ 1247a.1(1)(1); see Schoonover et al., supra note 172, at 29. 
either knew he was committing the offense or was convinced in his mind he was committing the crime. ${ }^{212}$ Because the prosecution must show what was actually in the defendant's mind at the time the offense was committed, knowing is the most difficult mental state to prove. ${ }^{213}$ However, in the United States, the prosecution does not have to prove what was actually in the defendant's mind at the time the crime was committed; the prosecution must only prove that knowledge could have been inferred from the surrounding circumstances by a reasonable person. ${ }^{214}$ The task of proving an employer had actual knowledge of a new hire's immigration status is much more difficult than proving an employer should have known about the individual's immigration status based on the surrounding circumstances. ${ }^{215}$ Thus, the United States has a much lower burden of proof than the United Kingdom with respect to proving an employer knowingly employed illegal workers.

Also, Section 8 does not include a specific provision prohibiting discrimination, but instead relies on pre-existing legislation to deter discriminatory employment practices. ${ }^{216}$ On the other hand, the IRCA includes specific anti-discrimination provisions and methods of enforcement. ${ }^{217}$ The fact that anti-discrimination offenses are not specifically included in the 2006 Act is not as significant as the other differences between the two acts because employers must still comply with the anti-discrimination laws included in preexisting legislation. ${ }^{218}$

The United Kingdom does not require employers to verify employment eligibility; ${ }^{219}$ whereas, employment eligibility verification is mandatory in the United States under the IRCA. ${ }^{220}$ Interestingly, the United Kingdom passed legislation in 2006, the Immigration, Asylum and Nationality Act 2006 (2006 Act), ${ }^{221}$ which was intended to remedy the problems of Section 8 , and, on the surface, it appears to make the system almost identical to the U.S. system under the IRCA. The 2006 Act excuses employers from sanctions if they can prove compliance with requirements set out by the Secretary of State in a Code of

212. The Law Commission, Criminal Law: Report on the Mental Element in CRime (LAW COM No. 89), 1978, H.C. 499, at 10 (implementation rejected).

213. Id. at 9.

214. 8 C.F.R. $\$ 1247$ a.1(1)(1) (2006); see Schoonover et al., supra note 172, at 29-30.

215. In the United States, knowledge can be proven through circumstantial evidence. 29 AM. JUR. 2D Evidence $\$ 557$ (2007).

216. Ryan 1997, supra note 149 , at 141-42.

217. Marinelli, supra note 44, at 846 (citing 8 U.S.C. $\$ 1324 b(g)(2)(B)$ (Office of Special Counsel for Immigration Related Employment Practices)).

218. Race Relations Act, 1976, c. 74 (Eng.) and Race Relations (Northern Ireland) Order, 1997 , SI 1997/869 (N. Ir. 6).

219. Ryan 1997, supra note 149, at 139; HOME OFFICE, COMPREHENSIVE 2004, supra note 188 , at 30 (stating "[y]ou [meaning the employer] will not commit an offence [sic] if you fail to keep a record for your employee and that person is not subject to immigration control ... or is permitted to work here").

220. 8 U.S.C. $\$ 1324 a(b)(2)(2006)$.

221. Immigration, Asylum and Nationality Act, 2006, c. 13, § 23. 
Practice order. ${ }^{222}$ The Code of Practice requirements include a process of employment eligibility verification similar to that required under the IRCA. ${ }^{223}$ Employers must check and copy specific documents indicating the individual is authorized to work; employers must also take "reasonable steps to check the validity of the original document and that the person presenting the document is the rightful holder. ${ }^{224}$ One difference between the U.K. and U.S. systems is re-verification. ${ }^{225}$ In the United Kingdom, employers are required to re-verify the eligibility status of employees who only have temporary authorization to work in the United Kingdom every twelve months. ${ }^{226}$ In contrast, United States employers are only required to re-verify an employee's eligibility on or before his or her documentation's expiration date. ${ }^{227}$

The 2006 Act also specifically requires the Secretary of State to issue a Code of Practice order providing employers information on how to avoid sanctions without engaging in discrimination. ${ }^{228}$ The Code of Practice suggests U.K. employers "treat all applicants the same way at each stage of the recruitment process." 229 This recommendation is similar to the IRCA antidiscrimination provision, which requires employers to ask all new hires for the same types of documentation to verify employment eligibility in the United States. ${ }^{230}$ Thus, the only real difference between the anti-discrimination measures in the United Kingdom and the United States is that the prohibition on discrimination in the United States has been specifically included in the IRCA and is an immigration offense, whereas, in the United Kingdom, discrimination is not an immigration offense, but is a violation of pre-existing legislation. ${ }^{231}$

While the two new provisions of the 2006 Act appear to remedy the discrepancies between the systems in the United States and the United Kingdom, further analysis reveals the 2006 Act has not significantly changed Section 8. As in the original Section 8 legislation, the actual requirements to verify employment eligibility through document checks and the requirement to

222. Home Office, Immigration, Asylum and Nationality Bill: Civil Penalties for Employers Draft Amount of Penalty Code of Practice, 2006, at 3 [hereinafter Home OfFICE, CIVIL PeNaltiES] (citing Immigration, Asylum and Nationality Act, 2006, c. 13, §15).

223. HoME OfFICE, Civil PENAlTiEs, supra note 222, at 5.

224. Id. at 9.

225. Id.; Dept. of Homeland Security, Employment Eligibility Verification, Form I-9, $\S 3$, available at http://www.uscis.gov/files/form/i-9.pdf (last visited June 2, 2008) [hereinafter DHS, Form I-9].

226. HoMe OFFIC, CIVIL PENALTIES, supra note 221, at 9 .

227. DHS, Form I-9, supra note 225, at 1 .

228. Immigration, Asylum and Nationality Act, 2006, c. 19.

229. HOME OFFICE, IMMIGRATION ASYLUM AND NATIONALITY BILL: DRAFT OF CODE OF PraCtICE For All EMPLOYERS ON THE AVOIDANCE OF RACE DISCRIMINATION IN RECRUITMENT Practice While Seeking to Prevent Illegal Working, 2005, at 13 [hereinafter Home OFFICE, DISCRIMINATION].

230. Martin \& Miller, supra note 23, at 35.

231. Race Relations Act, 1976, c. 74 (Eng.) and Race Relations (Northern Ireland) Order, 1997 , SI $1997 / 869$ (N. Ir. 6). 
avoid discrimination in employment practices are not included in the primary legislation, but, instead, are in supporting reports issued by the government. ${ }^{232}$ Unlike the IRCA, the supporting reports are not legally binding. ${ }^{233}$ Thus, the employment eligibility verification process is not mandatory for employers. ${ }^{234}$ The employment eligibility verification requirement in the United States is mandatory. ${ }^{235}$ As part of the IRCA, all U.S. employers are required to verify employment eligibility by filling out I-9 forms for each newly-hired employee. $^{236}$ Though the completed I-9 forms provide employers with a statutory defense, complying with the eligibility verification requirement is compulsory in the United States. ${ }^{237}$ By making the eligibility verification process mandatory and providing the forms on which employers must document the process, the United States' process of verification is standardized and ensures compliance by most U.S. employers. The system employed by the United Kingdom, on the other hand, relies heavily on the discretion of employers and is likely to lull some employers, especially those who do not feel as though they are at risk of prosecution for violations, into not verifying employment eligibility of new hires.

Other changes made by the 2006 Act, dealing with penalties, had more of an impact. ${ }^{238}$ The maximum amount of civil sanctions dropped from $£ 5000$

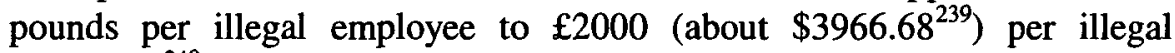
employee. $^{240}$ In assessing the amount of civil sanctions to impose, an Immigration Officer is to consider various factors to determine "the fairness of the financial penalty."241 These factors include: the extent of document employment eligibility verification checks conducted; past violations and

232. Home OfFice, Civil Penalties, supra note 222, at 3; Home Office, Discrimination, supra note 229 , at 11.

233. HOME OFFICE, DISCRIMINATION, supra note 229, at 5 (indicating

[t]he Code does not impose any legal obligations on employers, nor is it an authoritative statement of the law; only the courts and Employment Tribunals can provide this. However, the Code can be used as evidence in legal proceedings. Courts and Employment Tribunals must take account of any part of the Code that might be relevant on matters of racial discrimination in employment practices).

234. See id.; HOME OFFICE, COMPREHENSIVE 2004, supra note 188, at 30 (stating "[y]ou [the employer] will not commit an offence [sic] if you fail to keep a record for your employee and that person is not subject to immigration control ... or is permitted to work here"). The Secretary of State has yet to release the final Civil Penalties Code of Practice; this point is inferred from the language in the draft of the anti-discrimination code of practice and the Comprehensive Guidance report for employers published by the Home Office regarding 2004 legislation. Id.

235. 8 U.S.C. $\S 1324 \mathrm{a}(\mathrm{b})(2)(2006)$.

236. Id.

237. Id.

238. Immigration, Asylum and Nationality Act, 2006, c. 19. § 15; Ryan 2005, supra note 137 , at 41 .

239. Value current as of March 3, 2008. Go Currency, Currency Converter, http://www.gocurrency.com (last visited June 2, 2008).

240. Ryan 2005, supra note 137, at 65.

241. HOME OfFice, Civil Penalties, supra note 222, at 12. 
whether improvements have since been made; whether the employer reported suspected illegal workers to Immigration Services; whether the employer cooperated with the investigation; and the proportionality of the penalty to the infraction. ${ }^{242}$ The more remarkable addition to the penalties provisions is the possibility of prison sentences for offending employers. ${ }^{243}$ If an employer is convicted of knowingly employing a person who is ineligible to work in the United Kingdom, the employer can be sentenced to up to two years imprisonment. ${ }^{244}$ The length of the sentence depends on whether the employer is convicted on indictment or by summary conviction. ${ }^{245}$ Under the 2006 Act, corporate officers can be held accountable, along with the corporate body, for the actions of the business if the individual is found to have "consent[ed] or connive[d]" in the violation. ${ }^{246}$ This means corporate officers can serve time in prison if they personally have knowledge that the company is employing illegal workers. $^{247}$

The changes to the penalty provisions of Section 8 make the possible penalties for employing ineligible workers in the United Kingdom much harsher than the penalties in the United States. ${ }^{248}$ In the United States, employers who either hire an employee who is ineligible to work in the United States or fail to verify a new employee's eligibility are only subject to civil sanctions limited to fines. ${ }^{249}$ Employers could face prison time if they are found to have engaged in a pattern of employing illegal workers. ${ }^{250}$ If an employer is convicted of engaging in a pattern of employing illegal workers, he faces a maximum sentence of six month in prison. ${ }^{251}$ The United Kingdom's system is much more severe because an employer can be sentenced to prison time exceeding six months, even if they are convicted of only employing one illegal worker, so long as evidence indicates the employer consented or connived to violate the law. ${ }^{252}$ There does not need to be evidence demonstrating the employer has repeatedly violated the law in order for the maximum sentence to be imposed. ${ }^{253}$

242. Id.; see also Ryan 2005, supra note 137 , at 41 .

243. Ryan 2005, supra note 137, at 42.

244. Id.; see Richard McKee, Legislative Comment, The Immigration, Asylum and Nationality 2006 Act (and Other Developments), I.A.N.L. 2006, 20(2), 87-94, 92, 2006 WL 2088989 (Westlaw UK).

245. Ryan 2005, supra note 137, at 42; see J.R. Spencer, Does Our Present Criminal Appeal System Make Sense, Crim. L. Rev. 677-694 (2006) (significant differences exist between summary convictions and convictions on indictments, especially in the corresponding appellate procedures.).

246. Ryan 2005, supra note 137, at 42 (citing Immigration, Asylum and Nationality Act, 2006$, c. $49, \S 22)$.

247. Id, at 42 .

248. 8 U.S.C.A. § 1324a(f)(1) (2006); see supra Part III(A).

249. 8 U.S.C.A. $\$ 1324 \mathrm{a}(\mathrm{f})(1)$.

250. Id. (defining pattern as "regular, repeated, and intentional activities").

251. Id.

252. Immigration, Asylum and Nationality Act, 2006, c. 13, §22.

253. Id. 


\section{B. Enforcement}

\section{United States}

\section{a. Worksite Enforcement}

The INS was responsible for enforcing the employer sanctions provisions of the IRCA from $1986^{254}$ until March of 2003, when INS was absorbed into the Department of Homeland Security (DHS) and U.S. Immigration and Customs Enforcement (ICE), a subdivision of DHS, became responsible for enforcing the provisions via worksite raids. ${ }^{255}$

Immigration-enforcement agents start an investigation of an employer if they receive information that the employer is employing undocumented workers. $^{256}$ If agents believe the employer hired the undocumented workers unknowingly, agents review the employer's employment records, including the I-9 forms, and hold a seminar for the employer to educate it on how to properly complete the I-9 forms and how to detect fraudulent documents. ${ }^{257}$ Then agents provide the employer with a list of those employees believed to be undocumented and the employer is responsible for re-verifying their eligibility status or terminating their employment. ${ }^{258}$ If agents believe the employer knowingly hired undocumented workers, agents arrest the employer prior to the other steps of the investigation. ${ }^{259}$

Between 1992 and 1998, the INS had a memorandum of understanding with the Department of Labor Employment Standards Administration (DOL) to assist in worksite enforcement of the IRCA. ${ }^{260}$ The DOL agreed to collect information on employer compliance when engaging in standard labor investigations. ${ }^{261}$ Despite the promise of the underlying arrangement, the DOL was ineffective in IRCA enforcement for two reasons. First, the DOL did not

254. General Accounting Office, Illegal Aliens: Significant Obstacles to Reducing Unauthorized Alien Employment Exist, 7, GGD-99-33 (1999) available at http://www.gao.gov/archive/1999/gg99033.pdf [hereinafter GAO, Illegal Aliens: Significant Obstacles].

255. GAO, Immigration Enforcement: Weaknesses, supra note 181, at n.3. As part of the merger, INS's immigration functions were divided between three subdivisions of DHS: U.S. Citizenship and Immigration Services (USCIS), U.S. Immigration and Customs Enforcement (ICE), and U.S. Customs and Border Protection. Id.

256. GAO, Illegal Aliens: Significant Obstacles, supra note 254, at 7. An employer may also be randomly selected. Peter Brownell, The Declining Enforcement of Employer Sanctions, $\begin{array}{lllll}\text { MigRATION POL'Y INST., Sept. } & \text { 1, 2005, }\end{array}$ http://www.migrationinformation.org/Feature/display.cfm?ID=332.

257. GAO, Illegal Aliens: Significant Obstacles, supra note 254, at 7.

258. Id.

259. Id.

260. Espenoza, supra note 112, at 378; Martin \& Miller, supra note 23, at 34 .

261. Espenoza, supra note 112 , at 378. 
provide employers with the statutorily-mandated, three-day notice of intent to inspect the I-9 forms, and as result, could not inspect the documents. ${ }^{262}$ Second, the DOL was hesitant to provide INS with information about suspected undocumented workers because of concern individuals would be afraid to cooperate in labor law violation investigations. ${ }^{263}$ The partnership between INS and DOL was relatively unsuccessful for IRCA enforcement. ${ }^{264}$

The next enforcement attempt developed by INS was the General Administrative Plan (GAP), a process that would randomly select employers for the INS to audit for IRCA compliance. ${ }^{265}$ GAP had two parts: the General Inspections Program, which selected employers randomly from all geographic areas and industries, and the Special Emphasis Program, which selected employers randomly from industries known to have employed large numbers of undocumented workers. ${ }^{266}$ The General Accounting Office (GAO) found both programs were ineffective in reliably measuring compliance levels by either region or industry. ${ }^{267}$ The program left employer selection to regional offices, many of which had no selection guidelines, and those offices with guidelines were often so transparent that employers had implicit warning as to when they would be subject to I-9 inspections, thus giving employers time to prepare. ${ }^{268}$ Some employers did not fit within either program ${ }^{269}$ and, as a result, were not subject to any compliance review procedures. ${ }^{270}$ Other flaws to the enforcement strategy included not assessing the sanctions articulated in the IRCA, negotiating with companies to reduce the amounts of sanctions imposed, and not conducting re-inspections after finding violations. ${ }^{271}$ The GAO report recommended modifications to the INS enforcement strategy, including an automated system for maintaining compliance data. ${ }^{272}$

Worksite enforcement has been a low priority for immigration enforcement officials. ${ }^{273}$ In fiscal year 1999, INS dedicated nine percent of its total investigative agents to worksite enforcement, and, in fiscal year 2003, ICE

262. Id.

263. Martin \& Miller, supra note 23, at 34-35.

264. Id. (noting "[o]f the 367,000 employer Form I-9 reviews that the Labour [sic] Department conducted between FY 1988 and 1998, only 236 employers were suspected of employing unauthorized aliens and were referred to INS").

265. Espenoza, supra note 112, at 379.

266. Id. (citing General Accounting Office, Immigration Reform: Employer Sanctions and the Question of Discrimination, 94, GAO-GGD-90-62 (1990) [hereinafter GAO, Immigration Reform: Employer Sanctions]).

267. Espenoza, supra note 112, at 379 (citing GAO, Immigration Reform: Employer Sanctions, supra note 266, at 95 ).

268. Espenoza, supra note 112, at 379.

269. Id. The INS strategy "focused on large employers or those with a history of hiring undocumented workers." Id. at 380.

270. Id. at 379 .

271. Id.

272. Id. (citing GAO, Immigration Reform: Employer Sanctions, supra note 266, at 101).

273. GAO, Immigration Enforcement: Weaknesses, supra note 181, at 3. 
allocated only four percent. ${ }^{274}$ The number of worksite enforcement efforts dropped from 10,000 in fiscal year 1999 to 2200 in fiscal year $2003 .^{275}$ In 2001, after the terrorist attacks on the World Trade Center, the "INS shifted its [enforcement] focus to businesses related to the nation's critical infrastructure," including public and private businesses such as airports, military installations, nuclear power plants, federal buildings, and defense contractors. ${ }^{276}$ When ICE took over enforcement responsibilities from INS, it continued to focus its efforts on industries where employment of undocumented workers presented the greatest threat to national security. ${ }^{277}$

Available information suggests enforcement efforts and fines declined over several years. ${ }^{278}$ However, newer data indicates enforcement efforts have been on the rise in recent years. ${ }^{279}$ The number of arrests for administrative immigration offenses resulting from worksite enforcement raids fell from 2849 in 1999 to 445 in $2003 .^{280}$ The number of notices of intent to fine ${ }^{281}$ issued to employers dropped dramatically from 417 in 1999 to 3 in $2004 .^{282}$ Although, ICE reported significant increases in enforcement from 2004 to 2005 ; $^{283}$

274. Id. at 3-4.

275. Brownell, supra note 256 , at 8 .

276. GAO, Immigration Enforcement: DHS Has Incorporated Immigration Enforcement Objectives and Is Addressing Future Planning Requirements, 11, GAO-05-66, Oct. 2004 [hereinafter GAO, Immigration Enforcement: DHS]. "If these businesses were to be compromised by terrorists, this would pose a serious threat to domestic security." Id.

277. Id. at 12 (noting "ICE is pursuing this objective, now called critical infrastructure protection, by concentrating its enforcement resources on those industries where employment of illegal aliens poses the greatest potential threat to national security").

278. GAO, Immigration Enforcement: Weaknesses, supra note 181, at 16.

279. ICE, Worksite Enforcement Fact http://www.ice.gov/pi/news/factsheets/worksite.htm (last visited June 2, 2008).

280. GAO, Immigration Enforcement: Weaknesses, supra note 181, at 16.

281. Id. at $\mathrm{n} .25$ (indicating

[i]f warranted as a result of a worksite enforcement operation, ICE may issue a notice of intent to fine to an employer that specifies the amount of the fine ICE is seeking to collect from the employer. This amount may be reduced after negotiations between ICE attorneys and the employer).

282. Id. at 16 .

283. Id. at 18.

Data from fiscal years 2004 and 2005 cannot be compared with data for previous fiscal years because the way INS agents entered data on investigations into the INS case management system differs from the way ICE agents enter such data into the ICE system. Following the creation of ICE in March 2003, the case management system used to enter and maintain information on immigration investigations changed. With the establishment of ICE, agents began using the legacy U.S. Customs Service's case management system, called the Treasury Enforcement Communications System, for entering and maintaining information on investigations, including worksite enforcement operations. Prior to the creation of ICE, the former INS entered and maintained information on investigative activities in the Performance Analysis System, which captured information on immigration investigations differently than the Treasury Enforcement Communications System. 
criminal arrests increased from 160 to 165 ; criminal indictments increased from 67 to 140; and convictions increased from 46 to $127 . .^{284}$ The number of individuals arrested as a result of worksite enforcement raids in 2005 for administrative immigration offenses increased to $980 .^{285}$ In 2007, ICE reported 863 criminal arrests and 4077 administrative immigration violation arrests. ${ }^{286}$

It should be noted that ICE lumps all criminal arrests together and does not publish statistics differentiating between employers and illegal workers. ${ }^{287}$ ICE has also indicated those who are arrested for administrative immigration violations are generally undocumented workers who are in the United States illegally. ${ }^{288}$ Therefore, it is difficult to ascertain the number of employers ICE has held accountable for violating IRCA's prohibition on employing undocumented workers.

In April of 2006, ICE announced a new interior immigration enforcement strategy. ${ }^{289}$ A primary goal of the new strategy is to "build strong worksite enforcement and compliance procedures to deter illegal employment . . . ."290 The strategy also includes plans to bring criminal charges against employers who knowingly hire undocumented workers ${ }^{291}$ and to seize illegally-derived assets from violating employers. ${ }^{292}$ An example of these stepped-up enforcement efforts was Operation Wagon Train, which occurred on December $12,2006 .{ }^{293}$ During this operation, ICE immigration officials raided Swift \& Co. meatpacking plants in six states and arrested 1297 illegal workers. ${ }^{294}$ According to ICE, this was their largest worksite enforcement operation ever. ${ }^{295}$ However, ICE did not arrest or charge any company officials with IRCA

Id. at $\mathrm{n} .26$.

284. Id. at 18.

285. Id. Up from 445 in 2003 . See supra note 280 and corresponding text.

286. ICE, Worksite Enforcement Fact Sheets, supra note 279.

287. Id.

288. Id.

289. Press Release, Department of Homeland Security Unveils Comprehensive Immigration Enforcement Strategy for the Nation's Interior (Apr. 20, 2006), available at http://www.dhs.gov/xnews/releases/press_release_0890.shtm.

290. Id.

291. Id; GAO, Immigration Enforcement: Weaknesses, supra note 181, at 19 (stating "DHS has proposed increasing agent and support resources by 206 positions for all of its worksite enforcement efforts in 2007 to increase investigations of employers who hire significant numbers of unauthorized workers"). General Accounting Office, Immigration Enforcement: Benefits and Limitations to Using Earnings Data to Identify Unauthorized Work, 4, GAO-06814R, July 11, 2006, available at http://www.gao.gov/new.items/d06814r.pdf [hereinafter GAO, Immigration Enforcement: Using Earnings Data].

292. Press Release, supra note 289.

293. Jennifer Talhelm, Senators Meet on Recent Immigration Raid, WASH. PoST, Jan. 23, 2007, available at http://www.washingtonpost.com/wpdyn/content/article/2007/01/23/AR2007012300404.html.

294. Id.

295. Julie L. Myers, Assistant Secretary, ICE, Remarks at a News Conference Announcing a Worksite Enforcement Operation at a Nationwide Meat Processor (Dec. 13, 2006), available at http://www.ice.gov/doclib/pi/news/testimonies/061213wseo.pdf. 
violations. ${ }^{296}$ There are sixteen other examples of worksite enforcement operations listed on the ICE website and, in each of those cases, ICE either has brought criminal charges against the employers or has seized employer assets. ${ }^{297}$ ICE carried out another worksite enforcement operation against a national company on February 22, 2007, which led to the arrest of company officials on several criminal charges in connection with their practice of knowingly employing illegal aliens. ${ }^{298}$ While it is too early to tell whether these enforcement operations will have a deterrent effect on other employers there is some anecdotal evidence that suggests employers who contract with other companies to hire large numbers of workers may be more likely to take affirmative steps to independently verify the employment eligibility status of their employees. ${ }^{299}$

\section{b. Employment Eligibility Verification}

In order to comply with the verification requirements of the IRCA, and to avoid violating the anti-discrimination provisions, most employers do not request specific forms of identification and are often hesitant to assert that documentation appears to be fraudulent or unacceptable. ${ }^{300}$ The standard to avoid liability under the verification requirements is that the documents reasonably appeared to be genuine. ${ }^{301}$ This low threshold coupled with the large number of acceptable forms of identification ${ }^{302}$ has led to widespread use of counterfeit or fraudulent documents. ${ }^{303}$ The penalties for producing or selling counterfeit documents are minimal compared to the perceived gains. ${ }^{304}$ Another by-product of this low threshold is identity theft. ${ }^{305}$ According to data

296. Spenser S. Hsu \& Krissah Williams, Illegal Workers Arrested in 6-State ID Theft Sweep, WASH. Post, Dec. 13, 2006, at A1 (noting the fact no company officials were cited has been associated with the company's participation in the Basic Pilot program). Spenser S. Hsu, ICE Sweep Was Largest Ever Against One Firm, WASH. PosT, Dec. 14, 2006, at A9 [hereinafter Hsu, ICE Sweep]. See infra Part II(B)(1)(b).

297. ICE, Worksite Enforcement Cases, http://www.ice.gov/pi/news/factsheets/worksite_cases.htm (last visited June 2, 2008).

298. Julie L. Myers, Assistant Secretary, ICE, Remarks: RCI News Conference (Feb. 22, 2007).

299. Id.

300. See generally Martin \& Miller, supra note 23, at 36-37.

301. Marinelli, supra note 44, at 837 (citing 8 U.S.C. $\$ 1324 a(b)$ (1) (Supp. IV 1986)).

302. 8 C.F.R. $\S 1274 a .2(b)(1)(v)(2006)$. This provision lists fifteen acceptable forms of identification. Id.

303. Martin \& Miller, supra note 23, at 37, 45-46; see also GAO, Illegal Aliens: Significant Obstacles, supra note 254, at 10-11. "According to a January 1997 Justice Office of Inspector General (OIG) audit report, on the basis of a review of 30 INS fraud cases in 5 INS district offices, INS confiscated nearly 300,000 counterfeit documents." Id.

304. Id. at 45 . In 2000 , "sentences for those convicted of forging documents generally range[d] from ten months to six years in prison." Id.

305. See John Leland, Stolen Lives: The Crucial Number, N.Y. TIMES, Sept. 4, 2006, at A1 (detailing the recent trend in identity theft by illegal aliens for the purpose of establishing employment eligibility and the consequences for those who have had their identification stolen); 
from an INS employer sanctions database "from October 1996 through May 1998 , about 50,000 unauthorized aliens used 78,000 fraudulent documents to obtain employment." 306

When Congress passed the IRCA, it must have been aware of the potential for widespread document fraud under the new system, because one of the provisions included in the IRCA authorizes the President to monitor the current employment verification system and to implement improvements to the system if necessary to ensure that the system is secure. ${ }^{307}$ The President's authority is limited because he or she must get congressional approval on all major changes, ${ }^{308}$ and any changes must be counterfeit resistant, ${ }^{309}$ comport with timing ${ }^{310}$ privacy, ${ }^{311}$ and other requirements. President Reagan, who was in power when Congress passed the IRCA, refused to exercise the authority granted to him because he was concerned a new system would be too expensive and would result in privacy invasion. ${ }^{312}$

The U.S. Commission on Immigration Reform (CIR) echoed the concerns about fraudulent documentation in $1994 .{ }^{313} \mathrm{CIR}$ found the IRCA employer sanctions system had failed and recommended comprehensive reform including "measures designed to make it more difficult for illegal immigrants to obtain

see also General Accounting Office, Social Security Numbers: Ensuring the Integrity of the SSN, 5, GAO-03-941T, July 10, 2003, available at http://www.gao.gov/new.items/d03941 t.pdf [hereinafter GAO, SSN]. According to the SSA, over $80 \%$ of social security number misuse allegations are identity-crime related. Id.

306. General Accounting Office, Illegal Aliens: Fraudulent Documents Undermining the Effectiveness of the Employment Verification System, 2, GAO/T-GGD/HEHS-99-175, July 22, 1999, available at http://archive.gao.gov/f0902b/162489.pdf [hereinafter GAO, Illegal Aliens: Fraudulent Documents]. The GAO reports use the term ' 'fraudulent' . . to refer to situations in which unauthorized aliens illegally used documents for the purposes of obtaining employment. . .. [F]raudulent documents include documents that were illegally manufactured as well as genuine documents used illegally (e.g., an unauthorized alien using another person's valid document)." GAO, Illegal Aliens: Significant Obstacles, supra note 254, at 4 n.5.

307. 8 U.S.C. $\$ 1324 \mathrm{a}(\mathrm{d})(1)(2006)$.

308. 8 U.S.C. $\$ 1324 a(d)(3)(D)$. "Major change" is defined as:

(i) require [ing] an individual to present a new card or other document (designed specifically for use for this purpose) at the time of hiring, recruitment or referral; (ii) provid[ing] for a telephone verification system under which an employer, recruiter, or referrer must transmit to a Federal official information concerning the immigration status of prospective employees and the official transmits to the person, and the person must record, a verification code; or

(iii) require[ing] any change in any card used for accounting purposes under the Social Security Act [42 U.S.C.A. \$ 301 et.seq.]; including any change requiring that the only social security account number cards which may be presented in order to comply with subsection (b)(1)(C)(i) of this section are such cards as are in a counterfeit-resistant form consistent with the second sentence of the section 205(c)(2)(D) of the Social Security Act [42 U.S.C.A. § 405(c)(2)(D)].

Id.

309. 8 U.S.C. $\$ 1324 \mathrm{a}(\mathrm{d})(2)(B)$.

310. 8 U.S.C. $\$ 1324 \mathrm{a}(\mathrm{d})(3)$.

311. 8 U.S.C. $\$ 1324 a(d)(2)(D)$.

312. Spotts, supra note 49 , at 611 (citing LAHAM, supra note 126, at 162).

313. Martin \& Miller, supra note 23, at 41. 
work in the United States." 314 The commission found employers lacked the experience necessary to identify fraudulent documentation. ${ }^{315}$ CIR recommended the government issue new Social Security cards with credit-card type features to individuals authorized to work in the United States. ${ }^{316}$ The cards would allow for verification of employment eligibility by either swiping them through magnetic card readers or by calling a toll-free number. ${ }^{317} \mathrm{CIR}$ intended the proposed system to reduce the possibility that counterfeit documentation could be used in the employment eligibility verification process. ${ }^{318}$ CIR estimated the cost of creating a national registry would be between $\$ 250$ and $\$ 300$ million and would take approximately five years. ${ }^{319}$ In order to prevent large-scale problems that could cost more than initial estimates, CIR recommended the program be tested in a few states to work out any bugs before creating a national system. ${ }^{320}$

The cards proposed by CIR would contain personal information such as a birth date and fingerprint. ${ }^{321}$ Upon verifying the eligibility of the cardholder, CIR would supply the employer with one or two personal questions to ask the new hire to confirm that the individual presenting the card was indeed the appropriate cardholder. ${ }^{322}$ Civil liberties groups have attacked the proposed cards as a violation of privacy. ${ }^{323}$

As part of the Illegal Immigration Reform and Immigrant Responsibility Act of 1996 (IIRIRA), ${ }^{324}$ Congress required the Social Security Administration (SSA) to establish cost estimates for new social security cards incorporating counterfeit-resistant security features. ${ }^{325}$ The SSA found that issuing tamperresistant social security cards to the 277 million U.S. residents would cost between $\$ 3.9$ billion and $\$ 9.2$ billion. ${ }^{326}$ The General Accounting Office found these cost estimates to be reasonable. ${ }^{327}$

IIRIRA also required the SSA and INS to work together to test three possible means of electronic employment verification. ${ }^{328}$ The Basic Pilot, the

314. Id. (citing U.S. Immigration Commission on Immigration Reform, U.S. Immigration Policy: Restoring Credibility xxi (1994)).

315. Francis Gabor \& John B. Rosenquest IV, The Unsettled Status of Economic Refugees from the American and International Legal Perspectives-A Proposal for Recognition Under Existing International Law, 41 TEX. INT'L L.J. 275, 293 (2006).

316. Martin \& Miller, supra note 23, at 46.

317. Id.

318. Gabor \& Rosenquest, supra note 315, at 293.

319. Martin \& Miller, supra note 23, at 46.

320. Id.

321. Id.

322. Id.

323. Id. at 47 .

324. 8 U.S.C. $\S 1324$ a(b) (2006). IIRIRA was enacted as a piece of a larger bill, the Omnibus Consolidated Appropriations Act, 1997, Pub. L. No. 104-208.

325. GAO, Illegal Aliens: Fraudulent Documents, supra note 306, at 5.

326. Id. at 1, 5; see also Martin \& Miller, supra note 23, at 34.

327. GAO, Illegal Aliens: Fraudulent Documents, supra note 306, at 6.

328. GAO, Immigration Enforcement: Weaknesses, supra note 181, at 5. In 2003, two of 
most successful of the programs, is an automated system, which matches information voluntarily provided by employers about newly-hired employees ${ }^{329}$ to the information stored by SSA. ${ }^{330}$ If the employment eligibility cannot be verified by SSA information, then the data is compared to the DHS database. ${ }^{331}$ If the information cannot be verified by the DHS database, then it is referred to DHS immigration status verifiers who search other DHS databases. ${ }^{332}$ If an employee's employment eligibility cannot be verified via any of the aforementioned channels, then either SSA or DHS contacts the employer who then notifies the employee of the tentative non-confirmation. ${ }^{333}$ The employee has an opportunity to contest the non-confirmation within eight days; if the employee is successful in his contest, the employee's eligibility is confirmed, and if not confirmed, he is to receive a final non-confirmation. ${ }^{334}$ Employers are required to immediately dismiss employees whose work-eligibility status is not confirmed through this process or notify DHS of the continued employment of the non-confirmed individual. ${ }^{335}$ The purpose of the Basic Pilot is to test whether an electronic employment verification system will improve the existing system by decreasing "(1) false claims of U.S. citizenship and document fraud; (2) discrimination against employees; (3) violations of civil liberties and privacy; and (4) the burden on employers to verify employees' work eligibility." ${ }^{336}$ When the INS created the Basic Pilot in 1997, it aspired to have 16,000 employers enrolled by October $1,1999 .{ }^{337}$ As of June 2006, only 8600 employers, a small percentage of the total American employers, had become participants in the Basic Pilot program. ${ }^{338}$ Of those only 4300 were active participants. ${ }^{339}$

Interestingly, the U.S. Citizenship and Immigration Services (USCIS) division of DHS is responsible for oversight of the Basic Pilot program, even though ICE is responsible for worksite enforcement. ${ }^{340}$ The information shared through the Basic Pilot program could be used by ICE to locate employers who are not adhering to the provisions of the IRCA and could improve the worksite

the programs, Citizen Attestation Verification Pilot Program and the Machine-Readable Document Pilot Program, were discontinued for "technical difficulties and unintended consequences." Id. at n.9.

329. Id. at 5 (information is matched within three days of the employee's hire date).

330. Francesca Jarosz, Immigration: What's an Employer to Do?, BUS. L. TODAY, Dec. 16, 2006, at 51 .

331. GAO, Immigration Enforcement: Weaknesses, supra note 181, at 5-6.

332. Id. at 5-7.

333. Id. at 6-7

334. Id.

335. Id.

336. Id. at 5.

337. Martin \& Miller, supra note 23, at 38.

338. GAO, Immigration Enforcement: Weaknesses, supra note 181, at 9-10. The most current data available as to the total number of firms in the United States is 5.6 million, which was calculated in 2002. Id. at n.18.

339. Id. at 10.

340. Id. 
enforcement efforts of ICE. ${ }^{341}$ But USCIS is reluctant to provide ICE with access to this data because employers will refuse to participate based on the fear that participation will open them to worksite enforcement efforts. ${ }^{342}$ This is indicative of an interesting theme that carries throughout current U.S. immigration policy: the disconnect between employment eligibility verification and worksite enforcement. ${ }^{343}$

There has been debate in Congress about providing data collected by the SSA and other government agencies directly to ICE to aid in its enforcement efforts. ${ }^{344}$ Employers are periodically required to gather information from employees and to submit the information to various government agencies. ${ }^{345}$ This includes a duty to report tax information annually for each employee to the SSA, which corresponds with the individual employee's duty to file an income tax return with the IRS. ${ }^{346}$ In order to process a tax return, the IRS requires a taxpayer identification number. ${ }^{347}$ The taxpayer identification number is generally a social security number issued by SSA. ${ }^{348}$ Social security numbers are usually only issued to individuals authorized to work in the United States (i.e. citizens, legal permanent residents, etc.), but, in some circumstances, the SSA will issue social security numbers to non-citizens for non-work purposes. ${ }^{349}$ When the SSA does so, it is required to report to DHS any individual who has one of those numbers and who subsequently earns an income. ${ }^{350}$ Non-citizens who are not authorized to work in the United States

341. Id.

342. Id.; see also Thomas C. Green \& Illeana M. Ciobanu, Deputizing - and Then Prosecuting - America's Businesses in the Fight Against Illegal Immigration, 43 AM. CRIM. L. REv. 1203, 1212, 1216-20 (2006) (citing Editorial, Justice Department Fowl, WALL ST. J., Mar. 28,2003 , at A12). Tyson Foods was not only one of the first companies to volunteer for Basic Pilot, but was also instrumental in working with federal investigators to shut down a fraudulent document ring at one of its plants. Id. at 1213. Despite Tyson's compliance, the DOJ undertook a private investigation of Tyson; the investigation included the use of undercover agents posing as illegal alien smugglers. Id. at 1212 . As a result of the investigation, DOJ obtained a thirty-six count indictment against Tyson. Id. at 1223 . The district judge dismissed twenty-four of those counts, and after a five-hour deliberation, the jury acquitted Tyson on all remaining accounts. Id. at 1213. See also Stephanie E. Tanger, Enforcing Corporate Responsibility for Violations of Workplace Immigration Laws: The Case of Meatpacking, 9 HARV. LATINo L. ReV. 59 (2006).

343. GAO, Immigration Enforcement: Weaknesses, supra note 181, at 10; see generally GAO, Immigration Enforcement: Using Earnings Data, supra note 291, at 1.

344. GAO, Immigration Enforcement: Using Earnings Data, supra note 291, at 1.

345. Id. at 2.

346. Id.

347. Id.

348. Id.

349. Id.

350. Id. Through the time the GAO report was published (July 2006), DHS made little use of this information. Id. at 4. Though Congress passed the law requiring SSA to share this information in 1996, the format in which it was transferred was incompatible with DHS systems until 2005. Id. at 2,4. DHS claims this data would not be useful in locating employers who knowingly hire illegal workers, because all of the individuals have social security number. $l d$. at 
will usually not be issued a social security number; however, they can get an Individual Taxpayer Identification Number (ITIN) from the IRS for taxprocessing purposes. $^{351}$ The Treasury Office estimates the INS has issued hundreds of thousands of ITINs to illegal workers who have earned income in the United States. ${ }^{352}$

If the SSA finds a reported social security number does not match the corresponding name when it logs individual earnings, the SSA puts the earnings into an Earnings Suspension File (ESF). ${ }^{353}$ The earnings remain in the ESF until the SSA can match them to a valid name and social security number. ${ }^{354}$ When an employer submits a record that ends up in the ESF, the SSA sends an employer a no-match letter. ${ }^{355}$ Evidence suggests that a small proportion of employers account for the largest percentage of the unidentified earnings reports. ${ }^{356}$

In accordance with its recent announcement indicating it plans to press criminal charges against more employers, DHS would like to focus more of its enforcement efforts on employers who submit large numbers of inaccurate records. ${ }^{357}$ DHS has indicated it would benefit from having access to lists of employers who receive large numbers of no-match letters, regardless of whether the Basic Pilot program becomes compulsory. ${ }^{358}$ The data could provide DHS with two potential tools to assist in its enforcement efforts: leads to employers employing illegal workers, and evidence (in the form of received no-match letters) the employers had knowingly violated IRCA by employing undocumented workers. ${ }^{359}$

Though data sharing would benefit DHS's enforcement efforts, there are limits to what information government agencies can share. ${ }^{360}$ There are several laws aimed at protecting the privacy of individuals that limit the types and amounts of data that government agencies can share. "Because the confidentiality of tax data is considered crucial to voluntary taxpayer compliance, [the] IRS is restricted under Section 6103 of the Internal Revenue Code [(IRC)] from sharing taxpayer information with third parties, including

4.

351. Id.

352. Id.

353. Laura Fernandez Feitl, Caring for the Elderly Undocumented Workers in the United States: Discretionary Reality or Undeniable Duty, 13 ELDER L.J. 227, 235-36 (2005) (citing Jack E. Perkins, House Immigration Subcommittee Explores Social Security Totalization with Mexico, 80 No. 35 Interpreter Releases 1296, 1296 (Sept. 15, 2003)).

354. Feitl, supra note 353, at 235-36.

355. Id.; see Austin T. Fragomen, Jr. \& Steven C. Bell, Revisions to SSA "No-Match" Letter Program and Impact on Employers, IMMigr. Bus. News \& CMT., Apr. 1, 2003, at *1 (2003 WL 1560595).

356. GAO, Immigration Enforcement: Using Eamings Data, supra note 291, at 3.

357. Id. at 4.

358. Id.; Michael Chertoff, Secretary, DHS, Press Conference on Operation Wagon Train (Dec. 13, 2006), available at http://www.dhs.gov/xnews/releases/pr_1166047951514.shtm.

359. GAO, Immigration Enforcement: Using Earnings Data, supra note 291, at 3.

360. Id. at 5 . 
other government agencies, except in very limited circumstances." ${ }^{361}$ Section 6103 imposes the same restrictions on the SSA. ${ }^{362}$ Since worksite enforcement is not one of the limited circumstances allowed by Section 6103, Congress would have to enact a statutory exemption to provide DHS with access to taxpayer information. ${ }^{363}$ DHS Secretary Michael Chertoff has asked Congress to enact such a statute authorizing SSA to share data with DHS. ${ }^{364}$ A statutory exemption of this kind is likely to conflict with the Privacy Act, which stipulates data collected for one purpose cannot be used for a different purpose without either public notification or individual consent. ${ }^{365}$

\section{United Kingdom}

\section{a. Worksite Enforcement}

Prior to 1999, Immigration Officers (IO), agents of the Immigration and Nationality Directorate (IND), the government agency responsible for enforcing immigration policy in the United Kingdom, did not have as much authority as was necessary to enforce Section $8 .^{366}$ The Immigration and Asylum Act $1999^{367}$ expanded the IOs' authority to include the right "to search persons and premises, to enter premises for the purpose of searching and for arresting persons and to seize and retain relevant material."368 Initially, these powers were restricted to IOs operating within a pilot program, but the 1999 Act expanded these powers to include arrest teams that operate nationally. ${ }^{369}$ Even with these expanded powers, enforcement efforts have been relatively ineffective. ${ }^{370}$ Between 1998 and 2002, there were twenty-two prosecutions of employers for alleged violations of Section 8 and, of those, only eight resulted in convictions. ${ }^{371}$

Perhaps in response to those weak numbers, the Nationality, Immigration

361. GAO, Immigration Enforcement: Using Earnings Data, supra note 291, at 5.

362. Migration News, DHS: No Match Enforcement, http://migration.ucdavis.edu/mn/more.php?id=3315_0_2_0 (last visited June 2, 2008).

363. Id. The one exception to this would be information already allowed under the 1996 statutory exemption, which allows the SSA to share data concerning individuals who were issued social security numbers for non-work purposes but subsequently earned an income. $I d$. at 2 .

364. Hsu, ICE Sweep, supra note 296.

365. GAO, Immigration Enforcement: Using Earnings Data, supra note 291, at 5 (citing Privacy Act of 1974, Pub. L. 93-579, Dec. 31, 1974, 88 Stat. 1896).

366. IND, OPERATION MANUAL, supra note 199, § E, c. 46.

367. Immigration and Asylum Act, 1999, c. 33, \$§ 128-46.

368. IND, OPERATION MANUAL, supra note $199, \S \mathrm{E}, \mathrm{c} .46$.

369. Id.

370. Dhananjayan Sriskandarajah \& Francesca Hopwood Road Institute for Public Policy Research, United Kingdom: Rising Numbers, Rising Anxieties, Migration POLICY InSTITUTE, May 2005, at 8, http://www.migrationinformation.org/Profiles/display.cfm?ID=306.

371. Id. 
and Asylum Act $2002^{372}$ made further changes to the enforcement powers granted to IOs. ${ }^{373}$ The new powers granted under the 2002 legislation include the power to: (1) obtain a warrant to arrest an employer suspected of violating Section 8; (2) obtain a warrant to enter business premises to search for evidence of Section 8 violations; (3) enter and search business premises without a warrant to arrest immigration offenders if there are reasonable grounds to believe they are on the premise; and (4) search for and seize personnel records at business premises if there are reasonable grounds to believe Section 8 has been violated. ${ }^{374}$ The changes in the powers granted to IOs coincided with a renewed emphasis on enforcement operations. ${ }^{375}$

Between April and June 2003 the Immigration Service reported carrying out 79 illegal working operations, of which 27 were aimed at detecting significant numbers of illegal workers. Between July and September the number of reported operations increased by over $50 \%$ on the second quarter to 129 and those aimed at detecting a significant number of illegal workers rose by over $60 \%$ to 44 . $^{376}$

If IOs have been informed that a business is employing illegal migrants, the IND has set out specific procedures that must be followed in order to conduct worksite enforcement operations. ${ }^{377}$ First, IOs are under a directive to ensure they "have exhausted all avenues for resolving a person's immigration status in the UK [sic]." "378 To aid IOs in their background research, the IND has established Joint Intelligence Units charged with the mission of supporting enforcement visits. ${ }^{379}$ The Intelligence Units work together with police officers because of the highly-sensitive nature of these types of inquiries. ${ }^{380}$ The actual procedures used in the inquiries vary depending on whether the enforcement visits are to take place in metropolitan or regional areas. ${ }^{381}$ The metropolitan procedures generally include an initial visit request followed by local and police research. ${ }^{382}$ Once these are completed, an intelligence summary is created

372. Nationality, Immigration and Asylum Act, 2002, c. 41.

373. IND, OPERATION MANUAL, supra note 199, at c. 55.2.

374. Id.

375. IMMIGRATION AND NATIONALITY DIRECTORATE, REGULATORY IMPACT ASSESSMENT §7 (June 22, 2005), available at http://www.ind.homeoffice.gov.uk/sitecontent/documents/aboutus/consultations/closedconsultat ions/illegalworking/previouslypublished/ria2005.pdf?view=Binary [hereinafter IND, REGULATORY IMPACT ASSESS].

376. Id.

377. IND, OPERATION MANUAL, supra note $199, \S \S 46,55$.

378. Id. § 46.3.

379. Id. \& 46.3.1.

380. Id.

381. Id.

382. Id. 
which highlights any potential safety and community concerns. ${ }^{383} \mathrm{~A}$ "reconnaissance visit is then conducted and a risk assessment completed by the operational team ...."384 The risk assessment is forwarded to the investigation unit where an Intelligent Manager approves it. ${ }^{385}$ The investigation unit then seeks authorization for the local police inspector to conduct the enforcement visit. ${ }^{386}$ IOs must also obtain authority, in written form, for enforcement visits from middle or upper-level ranking immigration officials during this investigation process. ${ }^{387}$ Once officials give authorization, the information and clearance are given to the IO who initiated the process. ${ }^{388}$ The IO then must complete a final status check to determine the immigration status of the targeted individuals within twenty-four hours of the intended visit. ${ }^{389}$ IOs may only conduct enforcement visits after this entire process has been completed; if the IOs do not have the authority to arrest, they must seek police assistance in conducting the visit. ${ }^{390}$

IOs are instructed that enforcement operations should be planned with the goal of prosecuting the employer if possible. ${ }^{391}$ If IOs believe there is a possibility of being able to prosecute the employer, then IOs should make sure to have the necessary warrants to arrest the offenders and to search the premises for evidence. ${ }^{392}$ The IND operations manual instructs IOs to consider pursuing prosecution against employers even if the violation is the employer's first or is a minor offense, because the laws have been in place for over seven years. ${ }^{393}$

In recent years, the United Kingdom has appropriated more resources for enforcement efforts. ${ }^{394}$ The number of Immigration Service staff involved in enforcement operations grew by fifty percent between 2002 and $2004 .^{395}$ In 2003 to 2004 , the IND reported "700 enforcement raids took place - twice as many as the previous year." ${ }^{\text {,96 }}$ In 2006, Home Secretary John Reid announced the enforcement budget would be doubled by an extra $£ 100$ million $^{397}$ (about

383. Id.

384. Id.

385. Id.

386. Id.

387. Id. $\S 46.3 .2$.

388. Id. $\$ 46.3 .1$.

389. Id. $\S \S 46.3,46.3 .1$.

390. Id. § 46.3.1.

391. Id. $\$ 55.7$.

392. Id.

393. Id.

394. Immigration and Nationality Directorate, Press Release, New Powers Boost Immigration Officers Power to Protect UK Borders, Jan. 26, 2007, http://press.homeoffice.gov.uk/press-releases/441053?version=1.

395. Laura Dubinsky, Unauthorised Working, Background Paper 6, in LABOUR MIGRATION AND EMPLOYMENT RIGHTS (Bernard Ryan ed., 2005).

396. Home Office, Press Release, New Figures Show Accession Workers Working for the UK, Nov. 10, 2004, http://press.homeoffice.gov.uk/pressreleases/New_Figures_Show_Accession_Worke.

397. Home Office, Press Release, Immigration Charging Consultation Launched, Oct. 30, 
$\$ 198,333,994^{398}$ ), with the idea that this amount will allow enforcement efforts to also be doubled by 2009 . $^{399}$ The IND announced it would add 800 new immigration officers to the Intelligence Units to aid in enforcement efforts at the beginning of $2007 .^{400}$

\section{b. Employment Eligibility Verification}

Despite the increased enforcement efforts, the problem of employment eligibility verification, which as it stands, could undermine the whole system, remains. The parallel report released with the legislation by the government to assist employers with compliance makes it seem as though employment eligibility verification is a simple three-step process. ${ }^{401}$ Upon further examination, however, it is clear that a variety of types of documentation are allowed, several of which come in a variety of forms or with various stamps or endorsements. ${ }^{402}$ With the changes that came into effect in 2004, eight forms of identification could stand alone as proof of employment eligibility ${ }^{403}$ and sixteen combinations of documents could be used if the employee could not produce any of the stand-alone documents. ${ }^{404}$ The report also has eight pages describing the various stamps and approvals with which employers must be familiar to ensure a potential employee is authorized to do the type of work being offered. ${ }^{405}$ Employers are only required to take "'reasonable steps' to satisfy themselves that the document produced actually relates to the person who has provided it and that it gives them permission to do the job being offered." 406 "Reasonable steps" have been described as checking to ensure the photograph on the document looks like the person presenting it, ensuring the age of the person presenting the document corresponds with the birth date on the document, verifying the document has not expired, confirming stamps and endorsements on passports do not prohibit the potential employee from taking the type of job being offered, and asking for a third document to describe the discrepancy if the two documents presented contain different names. ${ }^{407}$ Because the penalties are assessed on the basis of various factors, including whether employers made checks of employment eligibility, ${ }^{408}$ and the employer

2006, http://press.homeoffice.gov.uk/press-releases/Immigration-Charging.

398. Accurate currency conversion as of March 3, 2008. Go Currency, Currency Converter, http://www.gocurrency.com (last visited June 2, 2008).

399. Home Office, Press Release, supra note 397.

400. Home Office, Press Release, Smarter, Larger Intelligence Led Units Boost Immigration Enforcement, Nov. 20, 2006, http://press.homeoffice.gov.uk/pressreleases/intelligence-led-units.

401. HOME OFFICE, COMPREHENSIVE 2004, supra note 188, at 4-5.

402. Id. at $8-24$.

403. Id. at $8-12$.

404. Id. at 13-24.

405. Id. at $46-54$.

406. IND, OPERATION MANUAL, supra note 199, § 55.4.

407. Id.

408. Home Office, Civil Penalties, supra note 222, at 4. 
is only expected to take "reasonable steps," illegal workers could easily avoid sanctions by claiming they made a good faith effort to take reasonable steps to verify employment status but were confused by the various types of identification allowed. This proposition is furthered by the fact that "[i]t has been made clear to employers that it is very unlikely that they will be taken to court if they establish a defence [sic]."410

Another problem with the employment verification process is the prevalent use of fraudulent documents by illegal workers to obtain employment. ${ }^{411}$ When Parliament initially passed Section 8 , an employer could verify a potential employee's employment eligibility status by examining either a British birth certificate or a document bearing a National Insurance number, neither of which contained a photograph of the bearer. ${ }^{412}$ In its guidance for employers, the Home Office even stated employers did "not need to worry about whether National Insurance numbers [were] genuine or belong[ed] to the person if [the employer] ha[d] seen an appropriate document." ${ }^{, 413}$ This left open the opportunity for individuals without proper authorization to use fraudulent documentation. $^{414}$ The government then modified the list of acceptable documents to eliminate this problem in the Nationality, Immigration and Asylum Act 2002, which came into effect in 2004 . $^{415}$ With the modifications, an individual can only use identification containing a photograph of the beholder as stand-alone eligibility documentation. ${ }^{416}$ Despite the changes, the British government indicated in 2005 that the use of forged documents continued to be the main reason why the number of prosecutions had remained low. ${ }^{417}$ As recently as January 2007 , the Minister for Nationality, Citizenship and Immigration, Liam Byrne MP, released a statement indicating over sixty forms of documents could be used to prove employment eligibility. ${ }^{418}$ Minister Byrne suggested the large number of forms of acceptable documentation creates many opportunities for forgery, and as a result, employer sanctions have been virtually unenforceable. ${ }^{419}$

409. IND, OPERATION MANUAL, supra note $199, \S 55.4$.

410. Id.

411. IND, REGULATORY IMPACT ASSESS, supra note 375, § 2(ii).

412. Ryan 1997, supra note 149 , at 139-41.

413. Id. at 141 (quoting HOME OFFCE, PREVENTION OF LLLEGAL WORKING: COMPREHENSIVE GUIDANCE FOR EMPLOYERS 15 (1996)).

414. Id. at 141 .

415. Ryan 2005, supra note 137, at 39. The Nationality, Immigration and Asylum Act 2002 also created a separate criminal offense for employers who employed A8 nationals who had not complied with their obligation to register within one month of starting new employment. Id. However, A8 workers cannot be removed from the country for this type of violation because A8 workers are EU citizens, and as such, it is highly unlikely this provision would be enforced. Id. at 40 .

416. Ryan 2005, supra note 137 , at 39.

417. IND, REGULATORY IMPACT ASSESS, supra note 375, §2(ii).

418. John Lettice, Immigrant ID Card to Recruit Employers as UK Border Police, THE REGISTER, Jan. 26, 2007, http://www.theregister.co.uk/2007/01/26/immigrant_id_card.

419. Id. 
In order to deal with the employment eligibility verification problems inherent in the United Kingdom's current system, the Home Office passed the Identity Card Act $2006{ }^{420}$ Under this Act, the British government launched the National Identity Scheme. ${ }^{421}$ The idea is "to create a single UK identity system. ${ }^{, 422}$ The program will provide identification including biometric data that can be used to verify a person's identity and eligibility to work. ${ }^{423}$ The types of biometric data envisioned by the system are fingerprints, iris data, and facial data. ${ }^{424}$ Another component of the program will be the National Identity Register, a government database that will hold the biometric information and link it to the biographical record of the cardholder. ${ }^{425}$ A primary purpose in creating a national identification card with biometric data was to combat illegal migration into the United Kingdom. ${ }^{426}$ Proponents of a biometric identification system claim it will improve efficiency in the efforts to prevent illegal working by allowing employers to verify a potential employee's identity and entitlement to work with one piece of identification as opposed to the complicated system currently in place. $^{427}$ The system also will help government enforcement operations in the same way. ${ }^{428}$

Despite its benefits, critics have met this new system with resistance. ${ }^{429}$ In addition to complaints about the costs associated with the program and the possibility that the program will not solve the illegal working program, ${ }^{430}$ there are serious concerns that this type of identification system has the potential to violate civil liberties. ${ }^{431}$ The use of biometric data on mandatory identification

420. Immigration and Nationality Directorate, Terrorism, ID Cards and Immigration Bills Become Law, Mar. 30, 2006, http://www.homeoffice.gov.uk/about-us/news/new-acts?version=2. The Identity Card Act 2006 was passed at the same time as a bill to combat terrorism and the Immigration, Asylum and Nationality Act 2006. Id. These measures are part of an overall effort to improve the immigration system and the Immigration and Nationality Directorate. See generally Home OFFIC, FaIR, EFFEctive, TRANSPARENT aNd TRUSTED: REBUILDING CONFIDENCE IN OUR IMMIGRATION SYSTEM (July 2006). Some have labled this new policy movement as "managed migration;" its aim is for the government to be able to control the flow of migration based on the labor needs of the economic market at any given time. See Flynn, supra note 154 , at 5-6.

421. Immigration and Nationality Directorate, supra note 420.

422. HOME OFFICE, BoRdERS, IMMIGRATION AND IDENTITY ACTION PLAN, 2006, at 4.

423. Id. at 5 .

424. Id. at 6.

425. Home Office, Strategic Action PLAN for the NATIONAL IDENTITY SCheme, 2006, at 10 [hereinafter HOME OfFICE, SAP].

426. Press Release, Home Office, Combating Illegal Immigration at Center of ID Card Plans, (Oct. 2, 2005), available at http://press.homeoffice.gov.uk/press-releases/illegalimmigration-id-card-plan?version $=1$.

427. HOME OFFICE, SAP, supra note 425 , at 10.

428. Id.

429. Lettice, supra note 418.

430. Id.

431. Mark Ballard, Conservatives Flesh Out ID Opposition, THE REG., Feb. 6, 2007; see also Rebekah Thomas, Global Commission on International Migration, Biometrics, Migrants, and Human Rights, MIGRATION POL'Y INST., Mar. 1, 2005, available at 
raises issues of information privacy. ${ }^{432}$ Human rights conventions have declared the right to privacy a fundamental right internationally, as well as in Europe and the United States. ${ }^{433}$ The United Kingdom has signed and ratified the UN International Covenant on Civil and Political Rights, in which Article 17 guarantees to protect every person from "arbitrary and unlawful interference with his privacy ....,434 Article 14 of the UN International Convention on the Protection of the Rights of All Migrant Workers and Their Families has assured the right to privacy to documented and undocumented migrant workers.. ${ }^{435}$ The aforementioned conventions share four principles: "[f]irst[], data must be obtained lawfully. Second, it also must be kept safely and securely. Third, it must be accurate and up-to-date, and finally, it must only be used for the original purpose specified." ${ }^{, 436}$ These principles may be difficult to maintain for a variety of reasons: ${ }^{437}$ the biometric data may be compromised due to the efforts of third parties, the data may become less reliable as the amount of it stored increases, and it is likely overtime data which was collected for one purpose may be used for entirely new purposes. ${ }^{438}$

Another argument is that the creation of a national identification system for preventing illegal working would be redundant; the same types of checks could be accomplished by cross-referencing the National Insurance numbers given by potential employees with the numbers retained by the Department of Works \& Pensions (DWP) and the Inland Revenue National Insurance Office (NICO). ${ }^{439}$ This proposal is similar to the proposal in the United States to link data from SSA and ICE to improve worksite enforcement efforts. ${ }^{440}$ Both of these proposals violate the fourth principle of the right to information privacy; private data would be used for purposes not specified when it was collected.

http://www.migrationinformation.org/Feature/display.cfm?ID=289.

432. Thomas, supra note 431 , at 2.

433. Id. (referring to Article 12 of the Universal Declaration of Human Rights, Article 17 of the UN International Covenant on Civil and Political Rights). The UN International Covenant on Civil and Political Rights was signed and ratified by the United Kingdom, but not signed or ratified by the United States. Signatures to the United Nations Covenant on Civil and Political Rights, http://www.hrweb.org/legal/cprsigs.html (last visited June 2, 2008). For more information about the Universal Declaration of Human Rights see Universal Declaration of Human Rights $50^{\text {th }}$ Anniversary, http://www.udhr.org (last visited June 2, 2008).

434. The United Nations International Covenant on Civil and Political Rights, Art. 17, I 1, available at $\mathrm{http}: / / \mathrm{www} . \mathrm{hrweb} .0 \mathrm{rg} / \mathrm{legal} / \mathrm{cpr}$.html (last visited June 2, 2008).

435. Thomas, supra note 431, at 2. However, neither the United Kingdom nor the United States has signed or ratified this convention. Office of the United Nations High Commissioner for Human Rights, International Convention on the Protection of the Rights of All Migrant Workers and Members of their Families, Ratifications and Reservations, available at http://www2.ohchr.org/english/bodies/ratification/13.htm (last visited June 2, 2008).

436. Thomas, supra note 431 , at 2.

437. Id.

438. Id.

439. Lettice, supra note 418. DWP is the government agency that distributes the benefits associated with National Insurance Contributions; NICO ensures the security and accuracy of National Insurance accounts. HM Revenue \& Customs, National Insurance Contributions Office-About Us, http://www.hmrc.gov.uk/nic/aboutus.htm (last visited June 2, 2008).

440. See supra Part II(B). 
While the creation of a new identification instrument and corresponding database for identity and employment eligibility verification would not violate this principle, because the use is included in the purpose of collecting the data, a new identification system could be at risk of violating either the principle requiring data to be securely stored or the principle requiring the data to be kept accurate and up-to-date. However, these risks are inherent with any form of identification or identification data storage system. Even the current systems are at risk of violating these principles.

\section{Comparing Enforcement Systems}

Neither the United States nor the United Kingdom has a perfect system for preventing employers from hiring illegal workers. Both can learn from the other to create a more effective system than either system currently in place. The United Kingdom could benefit from creating a compulsory, standardized process of employment verification for each new employee hired, similar to the I-9 form process in the United States. The United States could learn from the United Kingdom's system that a standardized form of identification linked to an independent database with the sole purpose of verifying identity and employment eligibility status would eliminate the privacy concerns associated with using social security numbers to verify employment eligibility. It would also benefit the United States to follow the lead of the United Kingdom and add some type of biometric information to the standardized identification instrument and database; and if not biometric, then at least it must contain a photograph. The one benefit biometric data has over photographs is that biometric data is harder to forge and, thus, will reduce the number of illegal workers who will be able to use fraudulent documents to obtain illegal employment. ${ }^{441}$

Overall, both systems seem to have the same hole: the disconnect between the employment eligibility verification systems and the worksite enforcement efforts by immigration officials. Employers should be required to verify employment eligibility for each new employee hired and then provide evidence of the check to the government agency responsible for worksite enforcement. That agency would then be able to cross-reference the submitted information with a database that would indicate the individual's identity and whether he or she is eligible to work. At that point, if the government agency discovered the data submitted by the employer indicates the new employee is not eligible to work, then the agency could conduct a risk assessment of the situation and, if needed, a worksite enforcement operation. This would save resources and be the most efficient solution: one agency would be responsible for the two interrelated tasks eliminating the problems with data-sharing

441. HOME OFFICE, SAP, supra note 425 , at 10 (indicating "[b]iometrics will tie an individual securely to a single unique identity. They are being used to prevent people using multiple or fraudulent identities"). 
between two agencies.

As it stands, in both the United States and the United Kingdom, there is a break at some point in the chain. In the United States the problem occurs because the government agency that receives the employee information from the employer (SSA) is not responsible for worksite enforcement efforts and does not have the authority to share information with the branch responsible for worksite enforcement (DHS or ICE). In the United Kingdom, the disconnect occurs at ground-level; employers are not required to verify employment eligibility of new employees. It is highly recommended that employers conduct eligibility checks; in fact, it is even rewarded because employers can use these checks to establish a defense for a violation. ${ }^{442}$ However, in order for the system to work, the checks must be compulsory.

Even if employment eligibility checks were mandatory and the national identification scheme was fully integrated into the current system, there would still be a problem. Once an employer verifies the employment eligibility of a new employee, the employer is not required to do anything else with the documentation it has copied and retained. Employers are not required to submit the documentation to a government agency for verification or for any other reason. This puts the entire onus of the system on the shoulders of the employer, and leaves it to the discretion of the employer as to when and if to verify employment status. For the United Kingdom's system to be effective, there must be some governmental oversight at this stage in the process. If the employer were required to submit the collected information to a government agency, employers would be more likely to participate in the system for fear of being caught not complying with the law. It is naive to expect employers to comply with a system that places an additional burden on them when there is no governmental oversight and a small likelihood of any consequence for noncompliance.

\section{RECOMMENDATIONS}

In the United States, immigration reform is at the forefront of a national political debate. ${ }^{443}$ President George W. Bush has asked for stronger employer sanctions and members of Congress and legal scholars have responded with various proposals. ${ }^{444}$ One proposal is to remove the mental state requirement and make employing illegal aliens a strict liability offense. ${ }^{445}$ This change would be advantageous in the areas of deterrence and enforcement. ${ }^{446}$ Employers would likely be more careful in their hiring and employment

442. Asylum and Immigration Appeals Act, 1996, c. 49, § 8(2).

443. Turner \& Rosenblum, supra note 13.

444. Id.; Jarosz, supra note 330; Gabor \& Rosenquest, supra note 315, at 287.

445. Jeffrey Manns, Private Monitoring of Gatekeepers: The Case of Immigration Enforcement, 2006 U. ILL. L. REV. 887, 967-68 (2006).

446. Id. 
eligibility verification practices in order to avoid liability. ${ }^{447}$ Also, this would decrease the costs associated with enforcement by lessening the burden of proof for the prosecution. ${ }^{448}$ However, at least two distinct disadvantages to a strict liability system exist: preemptive discrimination would likely increase and employers could be prosecuted even if they made every effort to comply with the law. ${ }^{449}$

Another proposal is to empower the DOL to have a larger role in employer sanctions enforcement. ${ }^{450}$ Though the DOL's law enforcement efforts are focused solely on worker protection, DHS has attempted in the past to use DOL's assistance in enforcing immigration-related worksite enforcement. $^{451}$ Such previous efforts have been unsuccessful for two reasons. $^{452}$ First, in order for the DOL to effectively enforce labor laws, it conducts worksite enforcement operations without warning employers beforehand. ${ }^{453}$ IRCA requires the government to give employers three days' notice before inspecting I-9 forms. ${ }^{454}$ Thus, DOL's enforcement method is incompatible with the statutory mandates of IRCA. Also, the DOL relies heavily on cooperation with employees and is reluctant to share information regarding immigration status of employees with the DHS out of concern that the illegal migrant community would no longer help DOL in the future. ${ }^{455}$ For these reasons, this proposal is not likely to work.

A third proposal is to create a system of employment eligibility verification based on the existing Basic Pilot. ${ }^{456}$ The proposed Employment Eligibility Verification System (EEVS) would require all employers to verify the names and social security numbers of employees with the SSA database. ${ }^{457}$ If SSA cannot verify an employee's authorization, then SSA will pass their information on to DHS for verification. ${ }^{458}$ If DHS cannot verify the employee's employment eligibility status, then the employee will have ten days to provide proof of their right to work before the employer may discharge them for being unauthorized. ${ }^{459}$ A potential problem with EEVS is that generally government databases have not been one hundred percent accurate. ${ }^{460}$ However, such problems exist in any database used for the storage of large volumes of information.

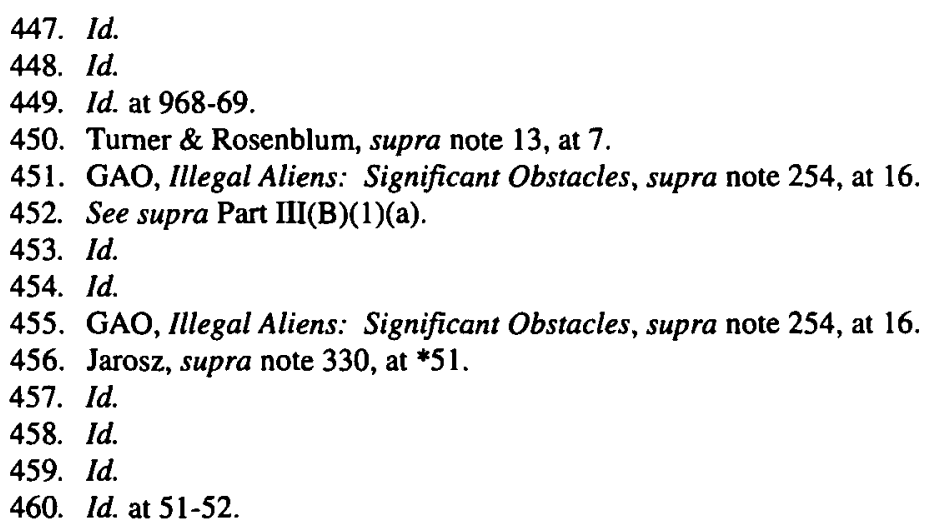


Another proposal building on the idea of instating EEVS calls for the use of "computerized and counterfeit-proof technology." EEVS and create a computerized registry, which stores identifiers unique to each individual authorized to work in the United States, similar to a social security number. ${ }^{462}$ A computerized, counterfeit-proof system of technology would have to be created to store the employee's unique identifier. ${ }^{463}$ Employers would be able to verify the employment eligibility status of a potential employee by checking the employee's identifier against a computerized registry. ${ }^{464}$ Employers would establish a defense to the offense of hiring illegal workers by verifying each employee on the computerized registry. ${ }^{465}$

This last proposal is similar to the system recently installed in the United Kingdom. ${ }^{466}$ The unique identifier in the United Kingdom's system will be biometric information, which is difficult, if not impossible, to forge. ${ }^{467}$ The biometric information will be stored on identification cards and in a national registry. ${ }^{468}$ Once the system is fully functional, employers will be able to verify the employment status of new employees by comparing the data on the identification cards with the national registry. ${ }^{469}$ The proposals in the United States regarding identification cards do not call for the creation of a new form of identification. ${ }^{470}$ Instead, they rely on the REAL ID Act of $2005 .^{471}$ The REAL ID Act sets national standards for state-issued drivers' licenses and identification cards and mandates that states must store information about cardholders. ${ }^{472}$ The problem with the REAL ID Act is that it violates one of the primary privacy principles, because the information the states are required to share was not collected for the purpose of verifying employment eligibility status. $^{473}$

The fundamental difference between the United Kingdom's system and the proposals in the United States is that the U.K. system is part of a comprehensive plan to overhaul immigration policy. ${ }^{474}$ The United Kingdom identified that its former immigration policies were not working and decided to change its entire system. ${ }^{475}$ Improving employer sanctions and the employment

461. Gabor \& Rosenquest, supra note 315, at 294.

462. Id.

463. Id.

464. Id.

465. Id.

466. See supra Part III(B)(2)(b).

467. Id.

468. Id.

469. Id.

470. Gabor \& Rosenquest, supra note 315, at 293.

471. Id.

472. Id.

473. See supra Part $\mathrm{II}(\mathrm{B})(2)(\mathrm{b})$.

474. See supra Part III(B)(2)(b), at note 420.

475. Id. 
eligibility verification process are part of the comprehensive changes; however, these changes are only one piece of the puzzle. ${ }^{476}$ The new approach to immigration recognizes there is a need for migrant labor to fill vacancies in the labor force of the United Kingdom. ${ }^{477}$ The goal is to assess the migrant labor needs of the marketplace accurately and to accommodate them by adjusting the flow of migration accordingly. ${ }^{478}$ In order to accomplish the goal of creating a system of immigration control, which is flexible enough to adapt to the changing needs of the labor market, the government must have the ability to track individual migrants. ${ }^{479}$ To do this, the government must rely on improved surveillance technologies, including the creation of identification cards and a national registry containing biometric information, and increased cooperation between various agencies. ${ }^{480}$ Though the task is sizeable, the United Kingdom has taken steps to begin the process and has a five-year implementation strategy. ${ }^{481}$

The proposals in the United States tend to focus on one aspect of the problem without attempting to address the whole system. Perhaps the idea of tracking all migrants and controlling the channels of migration to correspond with the needs of the labor market may be too large a task for the United States. Considering the number of illegal immigrants in the United States is twenty-one times the number of illegal immigrants in the United Kingdom, ${ }^{482}$ the United States may not be able to manage migration like the United Kingdom. However, it is possible for the United States to create a new system that, in addition to improving employer sanctions, also deals with the 11.6 million illegal workers already in the United States ${ }^{483}$ and the underlying factors that created and continue to perpetuate the problem. In creating changes, it is important for the United States to follow the the lead of the United Kingdom and overhaul the entire immigration system to create a new comprehensive policy instead of focusing its efforts on reforming specific parts of the existing system.

476. See supra Part III(B)(2)(b).

477. See Flynn, supra note 154 , at 6 .

478. Id.

479. Id.

480. Id.

481. Id.

482. See supra note 2 and accompanying text.

483. Briefing Paper 9.15, supra note 2 . 
